\title{
Exchange Trading Rules, Governance, and Trading Location of Cross-Listed Stocks*
}

\author{
Douglas Cumming \\ Professor and Ontario Research Chair \\ York University Schulich School of Business \\ Email: dcumming@schulich.yorku.ca \\ Web: http://ssrn.com/author $=75390$
}

\author{
Mark Humphery-Jenner \\ University of New South Wales, Australian School of Business \\ Tilburg University, European Banking Center \\ Email: m.humpheryjenner@unsw.edu.au. \\ Web: http://ssrn.com/author=493741 \\ Eliza Wu \\ University of Technology, Sydney, UTS Business School \\ Email: eliza.wu@uts.edu.au \\ Web: http://ssrn.com/author=377085
}

This draft: October 2011

\begin{abstract}
* We have benefitted from presentations and comments from conference and seminar participants at the Financial Management Association annual meeting American Law and Economics Association, the Cass EMG Conference, the Canadian Law and Economics Association, Finlawmetrics, the Finance and Corporate Governance Conference, McMaster University, University of New South Wales, University of Technology, Sydney, and York University. We also thank Kingsley Fong, Rick Harris, Sofia Johan, Ivalina Kalcheva, Sian Owen and Ron Masulis for their helpful comments.
\end{abstract}




\title{
Exchange Trading Rules, Governance, and Trading Location of Cross-Listed Stocks
}

\begin{abstract}
This paper shows stock exchange trading rules are of central importance for the trading location of cross-listed stocks. We consider various measures of sovereign governance and shareholder rights across countries to assess other legal and institutional drivers of trading activity. The data indicate that the proportion of trades that occurs on an exchange increases at a decreasing rate with the number of stock exchange trading rules. The effectiveness of stock exchange rules increases with the strength of regulatory institutions. Further, recent trading rule regulatory reforms pertaining to MIFID and RegNMS affect trading location.
\end{abstract}

Keywords: cross-listing, governance, trading rules, law and finance

JEL Codes: G15, G38, K22 


\section{Introduction}

This paper analyzes the role of sovereign governance and stock exchange rules in determining the location of trade for cross-listed stocks. Stock exchanges invest considerable resources and money on technology, regulation and manpower to promote market efficiency and integrity ${ }^{1}$. Exchanges that are based in jurisdictions with superior regulation and surveillance enjoy the benefit of more active trading (Cumming and Johan, 2008; Cumming, Johan and Li, 2011). For firms resident in jurisdictions that have inferior regulation or enforcement, there is a benefit to cross-listing in the U.S. to spur on trading activity (Halling et al., 2008; Gagnon and Karolyi, 2009). But despite the central role of trading rules governing the ways in which trades can take place on an exchange, there has been a comparative dearth of attention paid to how exchanges can structure securities laws in order to promote liquidity on their own exchange, particularly for cross-listed stocks.

This paper analyzes the reasons underlying the location of trading for firms that cross-list in the U.S. Non-U.S. companies might issue shares in the U.S. in order to obtain a 'liquidity' benefit by gaining access to U.S. markets. We examine how rules, regulations, and governance in non-U.S. markets influence the trading location of non-U.S. firms issuing stock both at home and in the U.S. We show that the proportion of non-US volume to US volume increases with sovereign regulatory strength, and increases with the strength of stock exchange rules (albeit at a decreasing rate). The impact of stock exchange rules increases with the strength of regulatory institutions. We also show that recent regulatory changes, such as MIFID, have influenced the location of trade for non-US stocks that cross-list in the US.

Sovereign governance and/or regulation should influence the location of trade for non-US stocks that cross-list in the US. The amount of non-US volume should increase with the non-US country's regulatory strength. This is because stronger regulatory institutions imply stronger law enforcement and lower corruption. This creates confidence in the equity market and should promote trade.

\footnotetext{
1 See: (Bhattacharya and Daouk, 2002, 2009; Daouk et al., 2006; Jackson and Roe, 2008; La Porta et al., 2006; Merrick et al., 2005; Ni et al., 2005; O'Hara and Mandiola, 2003; Peng and Röell, 2009; Pagano et al., 2001, 2002; Pirong, 1993, 1995a,b, 1999, 2004; Röell, 1992)
} 
Trading rules should affect the extent of trading for cross-listed stocks. Trading rules include restrictions on insider trading, market manipulation, and front running. ${ }^{2}$ The policy underlying trading rules is that they increase the integrity of market prices, which gives investors confidence to rely on market prices and encourages trade. ${ }^{3}$ Thus, prior studies show a clear relationship between rules and trading behavior. ${ }^{4}$ However, compliance can be costly, and excessively stringent rules might deter some brokers from operating in some markets (especially in regions where there are multiple stock exchanges). Further, we expect that the impact of trading rules will increase with the strength of the country's regulatory institutions, as strong rules that are not enforced are ineffective, and may be counter-productive (Bhattacharya and Daouk, 2009).

We test these predictions using a sample of non-US stocks that cross-list in the US and by examining the implementation of MIFID as a natural experiment. Our sample comprises non-U.S. firms listed on a U.S. exchange between 1996 and 2008. Our governance proxies are the World Bank governance indices, the ICRG composite index, the S\&P sovereign risk ratings, and the Spamann (2010) index. Our exchange rules variables derive from Cumming et al. (Cumming et al., 2011). We also examine the implementation of MIFID. MIFID is an attempt to harmonize and strengthen stock exchange rules in Europe. It is contemporaneous with Reg NMS in the US. MIFID has different rules from Reg NMS and has received criticism for being too stringent and/or vague in parts. $^{5}$

The results show the ratio of non-US volume to US-volume for cross-listed stocks increases with sovereign regulatory strength and stock exchange rules (but at a decreasing rate). The impact of exchange rules increases with the strength of regulatory institutions. Further, trade appears to have shifted out of Europe following the implementation of MIFID in November 2008, consistent with the prediction that MIFID has not been wholly effective in promoting trade in Europe. Our

\footnotetext{
${ }^{2}$ Cumming, Johan and Li (2011) show that trading rules comprise rules respecting insider trading, price manipulation, volume manipulation, spoofing, false disclosure and broker-agency conflicts.

${ }^{3}$ This underlies the 'fraud on the market' doctrine, which aims to deter people from issuing false statements that manipulate stock prices (Coffee, 2005; Fox, 2005; Coffee, 2006; Fox, 2006; Humphery-Jenner, 2011) .

${ }^{4}$ Prior studies suggest that trading rules influence trading behavior and drive stock market development (La Porta et al., 1998, 2006; Jackson and Roe, 2009). For example, prior studies show that markets with stronger insider trading laws are more liquid (Beny, 2005) and have less private informed trading (Durnev and Nain, 2007). Further, stronger securities laws reduce a firm's cost of capital (Lambert et al., 2007; Daske et al., 2008; Hail and Leuz, 2009). This has induced calls for tougher securities regulations (e.g. Merrick et al., 2005), and highlights why markets have expended considerable resources to improve market efficiency and limit market misconduct (Aitken and Siow, 2003; Comerton-Forde and Rydge, 2006).

${ }^{5}$ We describe MIFID and Reg NMS in Section 2.
} 
results are also robust to controlling for firm-specific, and country-specific factors, and for controlling for factors such as the information share of the US-market relative to the non-US market.

Our main contributions are four-fold. First, we highlight the importance of sovereign governance as a determinant of the location of trade. Second, we show that stock exchange rules influence the location of trade, although excessively stringent laws can deter trade. Third, we show the joint importance of rules and regulatory institutions. Fourth, we highlight the impact of MIFID and provide insights into its effectiveness. These results are important to exchanges, regulators, and governments that might want to increase the amount of volume in the home market. They results can indicate to companies the desirability of listing abroad, and are important to traders who might want to identify the most liquid market in which to trade a stock.

Our paper is related to a number of other important papers in the literature. First, the paper is related to prior work showing the importance of regulation to economic development (for example La Porta et al., 1997, 1998). Second, the paper is related to other literature showing the importance of stock exchange rules for market integrity (Cumming and Johan, 2008) and liquidity (Cumming et al., 2011). Third, this paper tangentially relates to the bonding literature.6 Non-U.S. companies sometimes list in the U.S. in order to ameliorate the effects of market segmentation and to increase liquidity (Miller, 1999; Foerster and Karolyi, 2000). This effect should work best if the U.S. market is more attractive to investors than is the non-U.S. market. That is, the benefits of bonding might be greatest if governance in the home market is the weakest. ${ }^{7}$ Fourth, Halling et al. (2008) analyze the location of trade for stocks that cross-list in the U.S. They find that some firm level characteristics determine the location of trade for stocks from developed markets but not for stocks from emerging markets. The results suggest that a further analysis of the impact of exchange rules and governance might be necessary to examine some additional drivers of the location of trade. They also highlight the desirability of determining whether particular regulatory changes, such as those due to MIFID, have been effective.

\footnotetext{
${ }^{6}$ The bonding literature is outside the scope of this article; however, it has received considerable support in the literature (Reese and Weisbach, 2002; Doidge et al., 2004, 2009a, 2009b) .

7 This follows the discussion in numerous prior studies (Reese and Weisbach, 2002; Doidge et al., 2004; Hail and Leuz, 2009) .
} 
The balance of the paper proceeds as follows. Section 2 outlines the hypotheses. Section 3 indicates the methods and sample. Section 4 contains the empirical results, and Section 5 concludes.

\section{Hypotheses}

In this section we develop three main hypotheses that are tested in the paper. The first hypothesis relates to country-level governance and risk. The second hypothesis relates to stock exchange rules. The third hypothesis examines MIFID in order to highlight the use of a natural experiment to test the impact of stock exchange rules. In all cases, our focus is on the ratio of volume in the Non-U.S. market ('Non-U.S.-Trade') to the volume in the U.S. market ('US-Trade').

\subsection{Home country governance}

We hypothesize that the ratio of Non-U.S.-Trade to U.S.-Trade should monotonically increase with the strength of the Non-U.S. country's legal regulation and governance. Here, regulation and governance refers to factors such as government stability, regulatory efficacy, the presence of the rule of law, and the presence of corruption. These factors do not impose a direct cost on traders or on brokers but do generate positive externalities by increasing confidence in the law.

Some literature indicates that country-level governance should improve market development. La Porta, Lopez-de-Silanes and Shleifer $(1997,2008)$ show that stock market development increases with regulation and governance. Halling et al. (2008) find a positive relationship between investor protection and the ratio of Non-U.S.-Trade to U.S.-Trade. ${ }^{8}$ McCahery, Sautner, and Starks (2010) use survey data to show that institutional investors consider sovereign governance when making investment decisions. Further, the bonding literature, which is non-core to this paper, suggests that companies from weak governance environments benefit the most when they list in the US (Reese and Weisbach, 2002; Doidge et al., 2004; Hail and Leuz, 2009). This implies that weak governance environments are unattractive to investors; and thus, that weak

8 Technically, their Table 4 uses a 'low investor protection' dummy and they find a negative relationship between 'low investor protection' and Non-U.S.-Trade/U.S.-Trade. 
governments should reduce the proportion of trade that concentrates in the non-US market. Overall this induces the following hypothesis:

Hypothesis 1: The ratio of Non-U.S.-Trade to U.S.-Trade should increase with the regulatory and governance strength of the Non-U.S. market.

\subsection{Exchange trading rules}

There should be a quadratic relationship between (a) stock exchange rules and (b) the proportion of trade in the U.S. market. We focus on 'investor protection' type rules rather than 'market mechanism' rules. We analyze rules on insider trading, price manipulation, volume manipulation, spoofing, broker-agency conflicts, and false disclosure.

The proportion of trade in the Non-U.S. market should initially increase with the strength of stock exchange rules. Brockman and Chung (2003) examine changes in the rules on the Hong Kong stock exchange. They find that stronger rules improve the liquidity of individual stocks. Hail and Luez (2006) show that strong exchange rules reduce a firm's cost of capital. La Porta, Lopez-deSilanes, and Shleifer (2006) show that disclosure rules backed by the threat of liability through private enforcement improve stock market development. Supporting this, Cumming, Johan, and Li (2011) show that an exchange's liquidity increases with the strength of its trading rules. These studies do not examine the location of trade; however, they do imply that strong rules should increase the amount of trade in the Non-U.S. market.

The relationship between Non-U.S.-Trade/US-Trade should be quadratic. There is some tangential literature on point. Burkart, Gromb, and Panunzi (1997) and Boot, Gopalan and Thakor (2006) show that the costs associated with high levels of disclosure and governance may deter managers from pursuing profitable investment opportunities. Bruno and Claessens (2010) indicate that strong governance companies in legally stringent countries trade at a discount to strong governance companies in legally 'flexible' countries. These studies show that requiring 'too much' compliance can reduce firm values. By parity of reasoning, requiring too much compliance and disclosure might deter brokerage firms from trading in a particular environment. Thus, there 
should be a quadratic relationship between the strength of the stock-exchange rules and the ratio of Non-U.S.-Trade to U.S.-Trade. This induces the following hypothesis.

Hypothesis 2: The relationship between exchange rules and the ratio of Non-U.S.-Trade to U.S.Trade should be quadratic.

We also expect that strong exchange rules are effective only if the regulatory institutions are strong. The intuitive rationale is that if regulatory institutions are weak, then there is inadequate enforcement of securities laws. Bhattacharya and Daouk (2009) support this, concluding that no law can be superior to a good law that is not enforced. For example, Humphery-Jenner (2011) argues that securities malfeasance is prolific in China because securities laws are not enforced rather than because the law is bad. Subsequently, we expect the ratio of non-US volume to US volume to increase with the interaction of 'Rules' and 'Regulation'. The following hypothesis captures this.

Hypothesis 3: The ratio of non-US volume to US_volume should increase with the interaction of 'Rules' and 'Regulation'.

\subsection{MIFID}

The hypothesis is that MIFID discouraged trade in the Non-U.S. exchange and shifted trade to the U.S. exchange. The European Union (EU) promulgated the Directive on Markets in Financial Instruments (MIFID) in May 2005. The implementation deadline was November 2007. MIFID is one part of the EU's attempt to implement the Lamfalussy Report. The Lamfalussy Report (broadly) states that the EU should create an integrated economic market (Committee of Wise Men, 2001). Thus, one aim of the Lamfalussy-reforms is to create "a stronger, deeper, pan-European capital market" (Prodi, 2002).

MIFID has several relevant traits. First, it harmonizes laws in six areas: insider trading, price manipulation, volume manipulation, spoofing, false disclosure, and broker-agency conflicts (Cumming et al., 2011). Second, it attempts to strengthen pre-trade and post-trade disclosure obligations. Third, Article 21 imposes a best-execution obligation on firms to "take all reasonable 
steps to obtain, when executing orders, the best possible result for their clients, taking into account price, costs, speed, likelihood of execution and settlement, size, nature".

There is some evidence that the MIFID reforms have increased liquidity. Cumming, Johan, and Li (2011) use a difference in difference (DD) model to show that MIFID increased liquidity in the EU. However, most firms listed in the EU do not have U.S. listings. Thus, they do not analyze whether investors prefer the EU if they have the choice to also invest in a company that also lists in the U.S.

There are several reasons why MIFID might shift trade from EU-markets to U.S.-markets. The over-arching theme is that the EU may have lost its competitive advantage (of having relatively strong companies in relatively weakly regulated markets) by increasing compliance costs without providing an off-setting benefit.

First, the increase in disclosure might discourage brokerage firms from advising clients to invest in the EU. Table 1 of Annex 1 in MIFID contains the disclosure requirements. The requirements appear comparable to those in other developed markets. However, (a) they are more onerous than the previous regulations, and (b) there is no unified reporting system or effective way to consolidate information (Giraud, 2009). Therefore, they may have increased the cost of operating in the EU without yielding a tangible benefit to brokers. This may shift trade to markets that have similar disclosure costs but that have more tangible disclosure-related benefits.

Second, MIFID's provisions are vague. Vagueness can be beneficial if it makes the law more flexible and adaptive to contemporary circumstances (Graham, 2002; Humphery-Jenner, 2009). However, uncertainty can impose transaction costs by creating legal uncertainty (Wagner, 2005, 2007). This legal uncertainty can deter people from undertaking particular actions (following Craswell and Calfee, 1986).

The best execution provisions in Article 21 highlight the problem of uncertainty. Here, firms must "take all reasonable steps...to obtain the best possible result for their clients..." (Article 21) is vague. Two key sources of vagueness are the definition of 'reasonable steps' and the definition of 'best possible result'. It is unclear what constitutes a reasonable step in this context. ${ }^{9}$ Further, while

\footnotetext{
${ }^{9} \mathrm{~A}$ 'reasonableness' standard is common in law. However, its definition depends on the context in which it appears. Given that MIFID is unique in its cross-border regulation of financial markets, there is no
} 
Article 21 does list factors the firm must consider when determining the 'best possible result' it does not indicate how firms should weight these factors, whether they should obtain information about the client's preferences, or whether they should use an arbitrary ex ante prediction of what a 'reasonable' client might deem best.

The implementation of MIFID in the EU was contemporaneous with the implementation of Reg NMS in the US. Under Reg NMS price alone matters for best execution duty, while under MIFID investment firms must comply with best execution duty by looking at a wide array of execution characteristics such as speed, and likelihood of execution and settlement. Reg NMS and MIFID also differ in terms of the trading data disclosure of trades' execution information. Reg NMS requires both markets and intermediaries to regularly disclose standardized information about the execution quality, and trading information is consolidated and available on a free market (Petrella, 2010). By contrast. MIFID does not require markets and intermediaries to consolidate trading information or trading venues, or to disclose execution quality (although MIFID still enables businesses to offer services that aggregate data from different trading venues). Petrella (2010) argues that MiFID was comparatively ineffective at reducing fragmentation. Aitken et al (2011) suggest that there was some post-MiFID reduction in market fragmentation, but fee reductions on Chi-X undermined this. By contrast, Harris et al (2011) indicate an increase in cointegration in the US following the introduction of Reg NMS.

The costs associated with complying with MIFID and the relative disadvantages to Reg NMS coupled with the uncertainty surrounding its implementation suggest that institutions will reduce trade in the EU. This implies the following hypothesis:

Hypothesis 4: MIFID reduces the proportion of trade that occurs in markets subject to MIFID obligations.

comparable Common Law or Statute Law from which to obtain the definition of 'reasonableness' in this context. 


\section{Methods and Sample}

\subsection{Sample}

Our sample comprises non-U.S. firms listed on a U.S. exchange between 1996 and 2008. There are 458 unique firms for a total of 3128 firm-year observations. The return and volume data comes from CRSP (for US data) and Compustat Global (for non-US data). Firm-level accounting data comes from Compustat. Data on country-governance comes from the World Bank governance indicators, International Country Risk Guide’s (ICRG) composite risk ratings, Standard \& Poors sovereign risk ratings, and Spamann's (2010) revised Antidirector Rights Index (ADRI). The World Bank does not report data for 1997, 1999, and 2001. For these years, we backfill data from the previous year (consistent with the approach in Gompers, Ishii, and Metrick, 2003; Masulis, Wang, and Xie, 2007; Bebchuk, Cohen, and Ferrell, 2008). The sample excludes firms that lack the required CRSP data, or Compustat company-level data. ${ }^{10}$

The variables come in four main categories: (1) dependent variables for volume, (2) governance variables, (3) trading rules variables, and (4) control variables. Table 1 provides definitions of all the variables used. The following sub-sections provide a detailed description.

--Table 1 About Here -

\footnotetext{
10 We also obtain some additional data for robustness tests (detailed in Section 4.3); however, most of these additional variables are country-level variables, which are captured through the inclusion of stock exchange and year dummies and are statistically insignificant in models that include stock dummies.
} 
We also examine additional variables in the tests reported in Section 4.3. These explore factors including transactions costs, the correlation of the firm's stock returns with the US market and the non-US market, emerging market dummies, exchange rate liberalization, and short sale restrictions.

\subsection{Dependent Variables}

The dependent variable is a measure of the ratio of non-U.S. trading volume to U.S.-trading volume. We do this by examining the U.S.-dollar volume trade that occurs in the non-U.S. market divided by the U.S.-dollar volume trade that occurs in the U.S. market. The computation process is as follows: (1) for each stock and each day obtain the number of shares traded in the U.S. market and the non-U.S. market. (2) For the U.S. market, multiply the number of shares traded by the share price to obtain $\$ V V_{\text {olume }}^{U S, t}$. (3) For the non-U.S. market, multiply the non-U.S. share price on day $t$ by the exchange rate for day $t$ by the number of shares traded in the non-U.S. market on day $t$ to obtain $\$$ Volume $e_{i, t}^{N o n-U S}$. (4) Compute the natural log of the ratio of non-US volume to US volume, denoted $\ln (\$$ Volume Ratio +1$)$. (5) Compute the average ratio over the course of the year because the control and governance variables are measured yearly.

\subsection{Key Independent Variables: The Regulation Variables}

The regulation variables are the key independent variables. We examine several sets of regulation, exchange rule, and governance variables. 
Exchange Rules: We expect that volume in the non-U.S. market has a quadratic relationship with the strength of the non-U.S. market's exchange rules. The exchange rule variables come from Cumming et al. (2011). They analyze the rules of stock exchanges across seven dimensions: price manipulation, volume manipulation, spoofing, false disclosure, market manipulation, insider trading, and broker-agent conflict rules. For each dimension, they assign a score representing the strength of the exchange's investor protection. We use (a) the score reported in Cumming, Johan, and Li (2011), (b) an equally weighted index (the Rule Index) of scores across the seven ruledimensions, and (c) the squared exchange rule score or exchange rule index. At the time of earlier directives such the 2004 Market Abuse Directive (MAD) in 2004, there were not associated efforts for surveillance (Cumming and Johan, 2008; Cumming, Johan and Li, 2011). Hence, as in Cumming, Johan and Li (2011), we use rule measures that are time-varying with the implementation of surveillance and enforcement mechanisms alongside the introduction of MIFID in November 2007.

MIFID: We analyze the effects of MIFID by using a difference-in-difference (DD) method. We create an indicator, I(MIFID), that equals one if the exchange comes under MIFID. We also analyze the date of the promulgation of MIFID (i.e. 2005) and the date of the implementation of MIFID (i.e. November 2007). We analyze the promulgation date separately (from the implementation date) in order to observe whether volume shifted from the MIFID-affected exchanges in anticipation of the implementation.

ICRG risk scores: The ICRG reports scores for various types of sovereign risk. The ICRG scores have seen some use in the literature (Erb et al., 1996; Gradstein, 2007; Boubakri et al., 2008). A higher score indicates a less risky country. We use the composite ICRG risk scores encapsulating economic, political, and financial risks. The ICRG reports a score for each month and we compute an annual ICRG score as the equally weighted monthly ICRG risk score. 
World Bank regulation and governance scores: The World Bank ranks countries on six dimensions of governance. The World Bank measures and ranks the government's accountability, corruption, government effectiveness, political stability, regulatory effectiveness, and the rule of law. ${ }^{11}$ The details of the construction of these measures are in Kaufmann et al. (2009). We compute an equally weighted average rank, which we denote the 'WB Governance Index'. Here, regulation and governance refers to factors such as government stability, regulatory efficacy, the presence of the rule of law, and the presence of corruption. These factors do not impose a direct cost on traders or on brokers but do generate positive externalities by increasing confidence in the law.

S\&P sovereign risk rating: Standard \& Poors report a sovereign credit risk score. High levels of credit risk may connote financial and political instability. Subsequently, Kaminsky and Schmukler (2002) show that sovereign credit ratings influence stock markets in emerging economies. We take the average sovereign credit rating across the year.

\subsection{Control Variables}

\subsubsection{Firm Level Variables}

Assets: Larger non-U.S firms are likely to be more attractive to U.S. investors than are smaller nonU.S. firms. The most likely explanation is that of all non-U.S. firms, large firms have the least information risk for U.S. investors. This is because (1) large firms tend to attract more analysts, and

11 These variables have received some prior use in the literature (Neumayer, 2002; Dollar and Kraay, 2003; Apodaca, 2004; Braun and Di Tella, 2004; Thomas, 2010) . 
the proximity to analysts improves the availability of information ; (2) large firms are more likely to be 'familiar' in nature to U.S. firms, and familiarity can increase returns (following Sarkissian and Schill, 2004); and (3) large firms are more likely to have the resources to properly over-come language barriers that would otherwise suppress returns (as in Grinblatt and Keloharju, 1999; Hau, 2001). Therefore, we expect a negative relation between assets and the \$volume ratio. Therefore, the models include the natural log of the firm's book assets: $\ln$ (Assets).

Debt/Assets: Financial leverage (proxied by the ratio of long term debt to assets) most likely reduces the portion of trade that occurs in the U.S. market. There are two key reasons. First, moderately high levels of leverage suggest that the firm has access to capital in the home market, which implies that the home market is relatively sophisticated and liquid. The implied attractiveness of the home market might encourage more trade in the home market. Second, while high leverage can help to ameliorate Jensen (1986) type agency costs of free cash flows, it can also impose bankruptcy risks (following Maloney et al., 1993). To U.S. investors, perception of bankruptcy risk might be higher for non-U.S. firms due to the latent level of information asymmetry associated with non-U.S. companies. Overall, these factors imply That Debt/Assets should increase the \$volume ratio.

Cash/Assets: Non-U.S. firms with higher cash holdings should be less risky and should be larger. Thus, in a similar way to assets (and a converse way to Debt/Assets), higher cash holdings should ameliorate information risk to U.S.-investors, and should increase the proportion of the firm's volume that locates in the U.S. market.

R\&D, Intangibles, and being High Tech: Firms with higher latent information asymmetry are less likely to attract interest from U.S. investors. This is because of the compounding of information 
asymmetry due to (a) firm-level factors and (b) the firm being domiciled in another country. Information asymmetry is likely to increase with the firm's use of R\&D, and Intangibles, and the firm's status as a high tech firm (following Gu and Wang, 2005). Given that no single variable is a good measure of innovation and technology (Kleinknecht et al., 2002), it is important to control for multiple measures in order to fully capture innovation and the information asymmetry associated therewith (Desyllas and Hughes, 2010). Therefore, the models include R\&D/Sales, Intangibles/Assets, and an indicator that equals one if the firm is a High Tech firm as defined in Loughran and Ritter (2004).

Advertising/Sales: A high level of advertising should correlate with higher trade in the U.S. market due to the firm's enhanced visibility. Supporting this, Grullon et al (2004) find that firms who spend more on advertising tend to have more investors, a more dispersed investor base, and higher liquidity. For non-U.S. firms, the gain from advertising is likely to be highest in the U.S. market, where the firm would initially have lower liquidity. This suggests a negative relationship between Advertisting/Sales and the \$volume ratio.

FCF/Assets: High free cash flows can induce Jensen (1986) type costs of free cash flow. Poor corporate governance can influence institutional investors' investment decisions (McCahery et al., 2010). Thus, high free cash flows might deter institutional investment in the stock, which might disproportionally reduce the amount of investment in the firm's U.S. stocks, which implies a positive relationship between FCF/Assets the \$volume ratio.

\subsubsection{Country level variables}

The characteristics of the non-U.S. market might influence the decision to (not) trade stock in that market. Thus, we control for several dimensions of home-market development. 
FDI: Home market development should increase with the level of FDI-to-GDP (Borensztein et al., 1998). Thus, the models include the ratio FDI/GDP, sourced from the World Bank.

Market capitalization: The market capitalization of the home market should increase volume in the home market. Thus, the models include the market cap of all companies listed in the non-U.S. market scaled by the GDP of the non-U.S. market (MktCap/GDP).

Turnover and market activity: The average turnover in the home market should influence the proportion of trade that concentrates in the home market for an individual stock. Two variables capture this. First, the models include the average \$volume ratio for all firms listed on the non-U.S. market. Second, the models include the average turnover of all stocks listed in the home market.

Taxation: High levels of taxation in the non-U.S. market might deter investors from investing in the non-U.S. market (following Hamada, 1966; Janeba, 1995). This might shift volume to the U.S. market. The models control for the highest level of corporate tax in the non-U.S. market. The data is from the World Bank. We acknowledge that this does not fully capture the nature of bilateral treaties on investment income; however, it does provide a proxy for the impact of taxation in the non-U.S. market.

Trade imbalance: The trade imbalance in the non-U.S. market can influence exchange rates. This can influence the relative attractiveness of investing in the home market (Giovannini and Jorion, 1987; following Bailey and Chung, 1995). Thus, the models control for the trade imbalance in the non-U.S. market, defined as (Imports - Exports)/(Imports + Exports). 
Time zone difference: Differences in time zones might deter US investors (say) from investing in the non-US issues of cross-listed stocks, and vice-versa (following Chen et al., 2008). This might influence the ratio of non-US volume to US volume. Subsequently, we control for the absolute value of the time zone difference between the location of the stock exchange and New York.

Language difference and geographic distance: Geographic distance can be a proxy for difficulties in obtaining and processing information between two locations (Ragozzino and Reuer, 2011). Thus, we control for the log-distance (in kilometers) between the non-US exchange and the US exchange. Further, language differences might make it more difficult to process information, especially for companies that trade in emerging markets, where rules and regulations might not always be available in English (MSCI, 2011). Thus, we include an indicator that equals one if the language spoken in the non-US exchange is English. ${ }^{12}$

Institutional shareholdings: We also control for the presence of US institutional shareholders. We obtain $13 \mathrm{f}$ holdings data for each firm in the sample. We control for total institutional shareholding in each firm at the beginning of the year scaled by the firm's total number of shares outstanding in the US market. The prediction is that a large institutional shareholding presence in the US will shift trade away from the non-US market because (a) the institutional shareholders typically account for a large portion of trading volume; and (b) institutional shareholders might make the US market more liquid; and thus, more attractive to non-institutional shareholders as well.

\footnotetext{
12 These exchanges are based in Australia, Canada, the United Kingdom, New Zealand, and Hong Kong.
} 


\subsection{Empirical Strategy}

We test our core predictions: governance increases the ratio of non-US volume to US volume; rules are quadratically related to the volume ratio; and the ratio of non-US volume to US-volume fell after the implementation of MIFID in those countries that MIFID affects. We also predict that stronger stock exchange rules will be more effective if the regulatory environment is stronger (i.e. we predict that the interaction of regulation with exchange rules will increase the ratio of non-US volume to US volume). The following models capture these hypotheses. Equations (1)-(3) examine governance and exchange rules. Equation (4) is a difference-in-difference model that examines the impact of MIFID.

$$
\begin{aligned}
& \ln (\$ \text { Volume Ratio+1 })=f(\text { Regulation, Controls }) \\
& \ln (\$ \text { Volume Ratio+1 })=f\left(\text { Rules, Rules }{ }^{2}, \text { Controls }\right) \\
& \ln (\$ \text { Volume Ratio+1 })=f(\text { Rules, Rules } \times \text { Regulation, Controls }) \\
& \ln (\$ \text { Volume Ratio+1 })=f(I(\text { MIFID }), I(\text { Date }), I(\text { MIFID }) \times I(\text { Date }), \text { Controls })
\end{aligned}
$$

Here, 'Rules' denotes variously one of the exchange rules variables pertaining to volume manipulation, price manipulation, broker-agent conflicts, spoofing, false disclosure, or insider trading. 'Regulation' denotes one of the measures of regulation (the WB governance index, the ICRG composite index, the Spamann (2010) ADRI, or the S\&P sovereign risk rating). 'Controls' denotes the control variables. For the difference in difference model in Equation (4), I(MIFID) is an indicator that equals one if the non-U.S. exchange is subject to MIFID. I(Date) is an indicator that variously equals one if (a) the observation post-dates the November 2007 implementation deadline; (b) post-dates the May 2005 date in which the EU promulgated MIFID, or (c) post-dates 
2005. Including stock-exchange dummies partially controls for the violations of the parallel trend assumption by controlling for unobserved exchange effects.

We estimate all models using Tobit with a lower bound of zero (consistent with Kayhan and Titman, 2007; Harford et al., 2009). The models also include fixed effects for year and for exchange and use robust standard errors. Our findings are robust to using standard OLS estimates, and to double-clustering standard errors by 3-digit SIC code and year (as suggested in Petersen, 2009), as we explicitly show in the tables in the next section. We report OLS results for some of our models (in Table 8 and Table 10). For brevity we do not report all OLS results. Alternative specifications are available on request.

\section{Results}

This section presents the results for univariate tests in part A and multivariate tests in part B. To summarize the results, the ratio of non-U.S.-volume to U.S.-volume (a) increases monotonically with sovereign governance, (b) has a quadratic relationship with stock exchange rules, and (c) decreased following MIFID in countries subject to MIFID, implying that the MIFID-inspired regulations do not achieve one desired policy purpose of shifting volume away from the U.S. to the EU.

\subsection{Univariate Results}

The univariate results suggest that home country governance influences the ratio of non-U.S. volume to U.S.-volume for non-U.S. companies with a U.S. listing. Summary statistics are in Table 2. 
They show skewness in the variables and suggest that it is necessary to winsorize the continuous variables. Table 3 contains the average governance index by year. The statistics show that the governance and exchange-rule variables are stable over time. ${ }^{13}$

--Tables 2 and 3 About Here -

The univariate results show a relation between governance, exchange-rules and the proportion of volume that trades in the non-U.S. market. Table 4 contains volume-ratio and governance variables by country. The statistics indicate that the proportion of volume traded in the home-market is higher if the various governance dimensions are higher. Table 5 contains pairwise correlations between the governance variables and the proportion of volume traded in the home market. The pairwise correlations suggest that (a) the ratio of non-U.S. volume to U.S. volume increases with governance and regulation in the home market, and (b) the various governance measures are significantly correlated with one-another.

--Tables 4 and 5 About Here -

\subsection{Multivariate Results}

The multivariate results yield three important conclusions briefly summarized as follows: (1) regulation, governance, and political stability monotically increases with volume in the non-U.S. market; (2) there is a quadratic relationship between non-U.S. volume and the strength of most

\footnotetext{
${ }^{13}$ Note that a country's exchange rule variables only change between 2007 and 2008. The changes over time before 2007 are due to changes in sample composition, which change the relative weight assigned to the ruleindex of each country.
} 
exchange-rules; and (3) MIFID has not achieved its aim of increasing liquidity and volume in the EU markets.

Governance and trade location: The first set of results considers the relation between measures of home-country governance and the ratio of non-U.S. to U.S. volume. Table 6 contains the regression results. There are two key results. First, the ratio of non-U.S. to U.S. volume increases with home-country governance. Columns 1-4 examine a linear relationship. The coefficient on all governance variables is positive and statistically significant, while the antidirector rights index (as measured by Spamann, 2010) is not. The economic significance is that 1 1-standard deviation change in the governance index causes an increase in the ratio of non-U.S. to U.S. volume by $40 \%$ (for the WB Governance Index), 57\% (for the S\&P Rating) and 34\% (for the ICRG Composite Index. Thus, investors are more willing to invest in the non-U.S. market if it has better governance. Second, the relationship between governance and the volume-ratio is not quadratic. Columns 5-8 include the quadratic governance term. This term is not significant in any model and is insignificant and positive in three of four models, which implies that improving governance will not reduce volume in the non-U.S. market.

--Table 6 About Here -

Exchange rules and trade location: The results show a quadratic relationship between the strength of stock exchange rules and the amount of volume in the non-U.S. market. Table 7 contains the results. Column 1 examines the exchange-rule-index. In Models 1, 2, 5 and 6 for the Rules Index, Price Manipulation Index, False Disclosure Index and Market Manipulation Index, respectively, the coefficient on the linear term is positive and significant but the coefficient on the quadratic term is negative and significant. The finding regarding the squared term implies that excessively onerous 
exchange-rules somewhat deter investors from the non-U.S. market. Regarding economic significance, however, the positive effect of more rules is large: a 1-standard deviation increase in the Rules Index variable gives rise to a $273 \%$ increase in the ratio of non-US volume to US-Volume, and this effect is $117 \%$ for the Price Index, $62 \%$ for the False Disclosure Index and $296 \%$ for the Market Manipulation Index. Note that while these results hold for many of the exchange-rule subindexes, the linear 'Broker' term is negative and significant whereas the quadratic 'Broker' term is positive and significant. An explanation could be that stringent broker-agent rules initially deter brokers from advising clients to invest in the non-U.S. market, and broker-agent rules are only beneficial after passing the initial deterrence threshold.

Table 8 contains models that control for both stock-exchange rules and sovereign governance. The first four columns contain Tobit results and the last four columns contain OLS results. The key finding is that the coefficients on the governance variable and the first-order rules variable are positive and statistically significant, whereas the quadratic rules variable is negative and statistically significant. The economic significance of these effects is very similar to that discussed above. This supports the foregoing results. ${ }^{14}$

--Tables 7 and 8 About Here -

Governance and Exchange rules: We also examine the interaction of sovereign governance and stock exchange rules. The prediction is that stronger stock exchange rules are effective only if there is effective regulatory enforcement. That is, we expect the interaction of 'Regulation' and 'Rules' to increase the ratio of non-US volume to US volume. The results are in Table 9. We find support for this prediction for all measures of regulation except the Spamann (2010) ADRI. This is a curious

\footnotetext{
${ }^{14}$ The findings are likewise robust to the inclusion of other control variables, including but not limited to surveillance efforts (Cumming and Johan, 2008; Cumming et al., 2011).
} 
result; however, a possible explanation is that the ADRI captures factors that are very similar to the stock exchange rules and has little per se to do with the strength of the regulatory institutions. This suggests that the interaction of the ADRI with the 'Rules Index' may behave more like the quadratic term in Table 7 and Table 8.

--Table 9 About Here--

MIFID: The MIFID results show that MIFID has not shifted trade to the home market. A preliminary point is that the parallel trend assumption (which is key to DD models) appears to broadly hold in the data. Figure 1 contains the ratio of non-U.S. volume to U.S. volume for countries that were subject to MIFID versus those that were not subject to MIFID. In most years, the volume ratio follows a similar trend for both countries.

--Figure 1 About Here -

The regression results are in Table 10 . The results are broadly consistent across tables. The variables of interest are the interactions of I(MIFID) with I(2008), I(2005), and I(Before or After not During 2005). The interaction term is negative in all models. The interaction 'I(MIFID) $\times I(2008)$ ' is significant and negative in models that either include or exclude stock exchange dummies. However, the interactions 'I(MIFID)× I(Before or After not During 2005)' and 'I(MIFID) x I(2005)' are not statistically significant. This implies that it is the implementation of MIFID, rather than its mere announcement, that induced the shift in the location of trade. Given the foregoing result that improving exchange-rules and governance tend to increase the proportion of volume in the home market, the MIFID results imply that MIFID has not adequately improved governance in the EU. 
Control variables: The control variables are largely consistent with expectations and are stable across models. (1) Size (proxy: 'In(Assets)') increases the proportion of trade that locates in the U.S. This finding implies that firm size increases financial stability, reduces information asymmetry, and makes companies more attractive to non-U.S. investors. (2) Debt reduces the amount of trade that occurs in the U.S. market. This suggests that the bankruptcy risk associated with high levels of debt discourages international investors. (3) Cash holdings increase the amount of trade that locates in the U.S. market. This finding implies that cash holdings connote financial stability and help to ameliorate the information asymmetry associated with non-U.S. companies. (4) The proportion of trade that locates in the U.S. decreases with R\&D/Sales and Intangibles/Assets, and is lower for high-tech firms. (5) The presence of institutional shareholders in the US shifts trade away from the non-US exchange. This quadrates with the idea that institutional shareholders account for a large portion of trade; and thus, increase the relative amount of trade in the US, and that the liquidity benefit of institutional shareholders might attract non-institutional shareholders to the market. These results likely reflect the fact that these firms are riskier and have higher levels of information asymmetry.

\subsection{Other Robustness Checks}

We establish that our results are robust to a wide range of model specification issues. First, they hold for various forms of clustering, holding in models that cluster standard errors by firm, or by 2,3 , or 4 digit SIC codes, and to double clustering with years. They also hold in models that include or exclude year dummies. 
Second, the results are robust to an alternative measure of relative trading activity computed as the ratio of non-US turnover/US turnover. The results are qualitatively the same as the ratio based on trading volumes.

Third, the results are robust to collinearity. The VIF for the variables does not exceed two, suggesting that collinearity is not a live issue in our analyses. Nonetheless, robustness tests also use principal component analysis to condense the variables into orthogonal components, which should not be collinear. The results hold in these models (unreported).

Fourth, the results are robust to time-period. The live issue is whether the results are robust to either (a) the Asian financial crisis, or (b) the tech-boom in the US during the sample period. To control for the Asian financial crisis, robustness tests exclude observations from before 1999. To control for the tech-boom, robustness tests exclude years 1999-2001. The results hold in both restricted samples.

Fifth, the results are robust to removing European firms from the sample. An issue is that the European stock exchanges consolidated over time. However, the results are qualitatively the same if we remove companies incorporated in European countries and/or remove companies that trade on an exchange that is based in Europe.

Sixth, the results are robust to controlling for an indicator, I(Tax Treaty), that equals one if there is a tax treaty between the US and the country of the non-US exchange. ${ }^{15}$ We find that the presence of a tax treaty increases the proportion of trade that occurs in the non-US market. This implies that a tax treaty induces US investors to invest outside of the US.

${ }^{15} \mathrm{~A}$ list is available here: $\underline{\mathrm{http}} / / / \mathrm{www} . \mathrm{irs} . \mathrm{gov} /$ businesses/international/article/0,id=96739,00.html 
Seventh, the results are robust to including an indicator, I(DJ Emerging), that equals one if the firm trades on an exchange based in an emerging market. ${ }^{16}$ They hold whether we include this in addition to, or instead of, the exchange dummies We find that if we remove the exchange dummies, then emerging markets have a significantly higher ratio of non-US volume to US-volume than do other markets (specifically, the coefficient on I(DJ Emerging) is positive and significant at $1 \%$ significance). Because the models use exchange dummies, we exclude this variable from the reported analysis.

Eighth, the results are robust to controlling for the ADR ratio. The ADR ratio is number of the company's ordinary shares that are equivalent to one American Depositary Receipt. This variable does not significantly influence the ratio of non-US volume to US volume.

Ninth, the results are robust to excluding periods in which there are short selling restrictions. Chen et al (2008) indicate that the availability of short selling can influence the rate of convergence between ADRs and home-market stock. Further, one possibility is that much of the volume in non-US stocks listed in the US comes from short selling (in an attempt to take advantage of mispricing between US issues and non-US issues). We note that at some point, the trader must unwind the short position; however, this can account for some short term differences in volume ratios. Subsequently, we control for this by excluding the crisis years of 2007 and 2008 within our sample period (or any one year individually). The results are qualitatively the same when we exclude these years.

\footnotetext{
16 The Dow Jones list of 35 emerging markets comprises: Argentina, Bahrain, Brazil, Bulgaria, Chile, China, Colombia, Czech Republic, Egypt, Estonia, Hungary, India, Indonesia, Jordan, Kuwait, Latvia, Lithuania, Malaysia, Mauritius, Mexico, Morocco, Oman, Peru, Philippines, Poland, Qatar, Romania, Russia, Slovakia, South Africa, Sri Lanka, Taiwan, Thailand, Turkey, and the United Arab Emirates.
} 
Tenth, the results are robust to controlling for the degree of exchange rate liberalization and/or the degree of foreign ownership allowed. We obtain the data from MSCI (2011). We create indicators that equal one if the country of the non-US exchange receives a 'negative' rating for foreign ownership limits or foreign exchange liberalization (MSCI assigns three ratings,,+++ , and ). Here, a 'negative' indicator for foreign ownership or foreign exchange liberalization reduces the proportion of trade that occurs in the non-US market; however, these variables are not statistically significant in models that include stock exchange dummies. In all cases, the results for the countrygovernance variables and the stock-exchange rules variables are qualitatively the same as the results reported.

Eleventh, the results are robust to controlling for measures of transactions costs either instead of, or in addition to, stock exchange dummies. Gagnon and Karolyi (2010) find that transactions/holding costs can influence deviations from price-parity for cross-listed stocks. This implies that holding costs/transactions costs could also influence the ratio of non-US trade to US trade. Specifically, of trading costs are higher in the non-US exchange, then there is likely to be less volume in that exchange. Stock exchange dummies should capture much of the exchange-specific differences in transactions costs. Nonetheless, we also examine the average high frequency percent realized spread, percent effective spread, and percent quoted spread (as reported in Fong et al., 2011). These are typically seen as reasonable daily measures of transactions costs and liquidity (Fong et al., 2011). The results are robust to controlling for these measures of liquidity/ transactions costs.

Lastly, the results are robust to controlling for the stocks relative correlation with returns in the home market and returns in the US market. Baruch et al (2007) hypothesize and find that the level of US trading volume for cross-listed stocks in part depends upon the correlation of (a) the 
returns on the firm's non-US stock with (b) the returns on the domestic market and the returns on the US market. That is, amount of US volume depends on (a) the correlation of the non-US stock with non-US assets, and (b) the correlation of the non-US stock with US assets. This is called the 'information share'.

The information share has a relatively ambiguous relationship with the ratio of non-US trade to US trade. Baruch et al (2007) find that the information share increases the level of volume in the US market. That is, the higher the correlation between home returns and US returns, the greater the amount of US trade. However, they do not examine the ratio of non-US trade to US trade (focusing instead on US volumes). Arguably, the information share could actually reduce the amount of US trade relative to the amount of non-US trade (i.e. increase the ratio of non-US trade to US trade). The rationale is that if there is a higher information share, then the home assets are more correlated with US assets. If they are more correlated with US assets, then US investors might be more willing to invest in the non-US markets (by parity of reasoning to why the information share increases the amount of US trade). Supporting this, Gagnon and Karolyi (2009) find that volume 'spills over' from the US exchange to the non-US exchange on high-volume days. That is, as more information is disclosed in the US market, the level of non-US market also increases. Thus, if non-US returns are more correlated with US returns, then it might attract US investors and might increase the ratio of non-US trade to US trade.

We capture this in the similar way to Baruch et al (2007). For each year we compute an 'information share' for the stock. We compute the information share by using daily stock returns and do so as follows. First, we run a 'restricted' model that assesses the relationship between the non-US returns and the non-US market (in Equation 5). Second, we run an 'unrestricted' mode that assesses the relationship between non-US returns, the non-US market, and the US market (in 
Equation 6). The goal is to assess the impact of information from the US market factor. We use lead and lag terms in Equation 5 and Equation 6 in order to control for non-synchronious trading (following Baruch et al., 2007).

$$
\begin{gathered}
r_{i, t}=\alpha_{i}+\sum_{k=-1}^{+1} \beta_{i, t+k} r_{\mathrm{Home}, t+k}+\varepsilon_{i, t} \\
r_{i, t}=\alpha_{i}+\sum_{k=-1}^{+1} \beta_{i, t+k} r_{\mathrm{Home}, t+k}+\sum_{k=-1}^{+1} \beta_{i, t+k} r_{\mathrm{US}, t+k}+\varepsilon_{i, t}
\end{gathered}
$$

Third, we compute the information share for the second model. That is, we calculate how much additional explanatory power the model gains by including the US market factor. We do this using a F-statistic, as follows:

$$
\begin{aligned}
& \text { Information Share }=\frac{\frac{\left[R_{U R}^{2}-R_{R}^{2}\right]}{p_{R}}}{\frac{\left[1-R_{U R}^{2}\right]}{n-p_{U R}}} \\
& \text { Where: } \\
& R_{U R}^{2}=R \text {-squared from Equation (6) } \\
& R_{R}^{2}=R \text {-squared from Equation (5) } \\
& n=\text { Number of observations } \\
& p_{U R}=\text { Number of parameters in Equation }(6)=6 \\
& p_{R}=\text { Number of parameters in Equation }(5)=3
\end{aligned}
$$

The results hold after controlling for the information share measure. The summary statistics for the information share are in Table 2, and are similar to those reported in Baruch et al (2007). The results are in Table 11. The information share measure is positively related to the ratio of non-US trade to US trade. This is consistent with the prediction that a higher information share might attract US investors. The governance variables and exchange rules variables have the same signs and similar significance levels to those in Table 8. 


\section{Conclusion}

In this paper, we examine the effect of exchange trading rules and other governance regulations on the location of trades for firms that cross-list in the U.S. Prior studies have identified cross-country variation in the location of trades for non-U.S. firms with U.S. stock-issues (Halling et al., 2010). Other studies have identified the importance of country-governance to stock market development and stock exchange liquidity, among other things (La Porta et al., 1997, 1998). In this paper we connect these strands of literature to examine whether sovereign governance and exchange rules drive the trading location for non-U.S. firms that cross-list in the U.S. Also, we use the implementation of MIFID as a natural experiment with which to test the importance of exchange trading rules.

The data indicate that stronger rules increase trading on non-U.S. exchanges for cross-listed stocks. However, the benefit of more rules diminishes as trading and compliance becomes more costly and the non-U.S. market loses its 'cheap compliance' competitive advantage. Our analysis of the MIFID natural experiment provides supporting evidence consistent with this view. Further, the data indicates that stronger governance monotonically increases the relative amount of trade that occurs in the non-U.S. market.

Overall, our results have implications for countries, firms, and exchanges. Countries can encourage more trade if they improve their regulation and governance, and reduce sovereign risk. This is an illuminating result given recent troubles with sovereign debt management, even in 
developed economies. Moreover, exchanges can obtain a greater share of trade if they strengthen stock exchange rules, but not so much that compliance becomes excessively costly. In the specific context of the EU, the results show that the costs of compliance outweigh the (possible) benefits in exchange liquidity. For corporations, they indicate the expected location of trade should they choose to list in the U.S. Future research could focus on, among other things, how stock exchange rules and country governance influence the relative efficiency of the market's reaction to corporate events. 
Table 1: Variable definitions

This table defines the variables. The return and volume data are from CRSP. Firm-level accounting data are from Compustat. Analysts data are from Thomson Reuter's Institutional Brokers' Estimate System (IBES). Data on country-governance comes from the World Bank. Exchange trading rules data are from Cumming, Johan and Li (2011).

\begin{tabular}{ll}
\hline Variable & Description \\
\hline Volume Variables & \\
\hline Daily \$Volume (Non-U.S.) & $\begin{array}{l}\text { The daily volume of shares traded in the non-U.S. market multiplied } \\
\text { by non-U.S. share price concerted to USD at the day's exchange rate } \\
\text { The daily volume of shares traded in the U.S. market multiplied by } \\
\text { the share price on the U.S. market }\end{array}$ \\
The yearly average of the ratio: Daily \$Volume (non-U.S.)/ Daily \\
TVolume Ratio & $\begin{array}{l}\text { \$Volume (US) } \\
\text { The equally weighted average 'Yearly \$Volume Ratio' for all stocks } \\
\text { traded on the non-U.S. market }\end{array}$
\end{tabular}

\section{Governance Variables}

WB Governance Index

S\&P Rating

ICRG Composite Index

ADRI Spamann

Trading Rules

Rule Index (2006)

Rule Index (2007)

Price Manipulation

Volume Manipulation

Spoofing

False Disclosure

Market Manipulation

Insider Trading Rules Index
The equally weighted average of the World Bank's governance 'rank' variables for political stability, government effectiveness, corruption, rule of law, regulation, and accountability

The S\&P sovereign risk rating

The composite governance index that ICRG reports

The antidirector rights index from Spamann (2010)
The equally weighted average of the 2006-2007 exchange rule ranks for Market Manipulation, Insider Trading and Broker Agency.

The equally weighted average of the 2007-2008 exchange rule ranks for Market Manipulation, Insider Trading and Broker Agency.

Sum of dummy variables for Marking the Open, Marking the Close, Misleading End of the Month/Quarter/Year Trades, Intraday Ramping / Gouging, Market Setting, Pre-arranged Trades, and Domination and Control.

Sum of dummy variables for Churning and Wash Trade.

Sum of dummy variables for Giving up Priority, Switch and Layering of Bids/Asks.

Sum of dummy variables for Dissemination of False and Misleading Information and Parking or Warehousing.

Sum of Price Manipulation Rules Index, Volume Manipulation Rules Index, Spoofing Rules Index, and False Disclosure Rules Index

Sum of dummy variables for Front-running, Client Precedence, Trading Ahead of Research Reports, Separation of Research and Trading, Broker Ownership Limit, Restrictions on Affiliation, Restrictions on Communications, Investment Company Securities, Influencing or Rewarding the Employees of Others, and Anti- 
Broker Agency Index

Controls
Debt/Assets)
Cash/Assets
US Institutional Holdings
ln(Distance from NY km)
Home Market Cap/GDP
Home Market Turnover
FDI/GDP
Trade Imbalance
abs(Time Zone Difference)
R\&D/Sales

I(Same Language)

Advertising/Sales

Intangibles/Assets

High Tech

FCF/Assets

Information Share
Intimidation / Coordination.

Sum of dummy variables for Trade Through, Improper Execution, Restrictions on Member Use of Exchange Name, Restrictions on Sales Materials and Telemarketing, and Fair Dealing with Customers.

The natural log of the total assets (Compustat: at)

The long term debt (Compustat: dltt) divided by the total assets (Compustat: at)

The firm's cash holdings (Compustat: ch) divided by the total assets (Compustat: at)

The percentage of US shares outstanding that institutional shareholders (under $13 \mathrm{f}$ obligations) own. We compute this at the beginning of the year. We obtain the $13 \mathrm{f}$ filings pertaining to each firm in the sample. For each company, we add the shareholdings of all institutional shareholdings at the beginning of the year. We then divided by the total number of shares outstanding in the US market (as reported in CRSP).

The natural log of the distance, in kilometers, between (a) NY, and (b) the primary non-US exchange on which the firm is listed.

The ratio of the market capitalization of all firms from the firm's home country divided by the country's GDP. Source: World Bank.

The stock turnover of firms from the present firm's home country. Source: World Bank.

The ratio of the home-country FDI to GDP, where the home country is the country in which the firm is located. Source: World Bank.

The trade imbalance of the country in which the firm is located. The trade imbalance is (Imports-Exports)/(Imports + Exports)

The absolute value of the time zone difference between (a) New York, and (b) the primary non-US exchange on which the firm is listed.

The firm's R\&D expenditure divided by its sales (Compustat: xrd/sale). We recode missing R\&D expenditure as 0, following MWX (2009)

An indicator that equals one if English is the national language of the country in which the firm's primary non-US exchange is located. Note that we also include Hong Kong as an English speaking country.

The firm's advertising expenditure divided by its sales (Compustat: xad/sale). We recode missing advertising expenditure as 0 , following MWX (2009)

The firm's intangible assets divided by its total assets (Compustat: intan/at). We recode missing intangibles as 0, following MWX (2009)

A dummy that equals one if the firm is high tech, as defined in Loughran and Ritter (2002)

The firm's free cash flow (Compustat: oibdp - xint - txt-capx) divided by its total assets (Compustat: at)

The information share computed in a similar way to in Baruch et al (2007). This is the F-statistic derived from comparing a the Rsquared from a restricted regression (that regresses the firm's nonUS returns on the market returns for the non-US market) and from an unrestricted regression (that also includes the returns on the US market). The restricted regression is in Equation (5) the unrestricted regression is in Equation (6). The information share is then: 


\begin{tabular}{l}
\hline Information Share $=\frac{\frac{\left[R_{U R}^{2}-R_{R}^{2}\right]}{p_{R}}}{\frac{\left[1-R_{U R}^{2}\right]}{n-p_{U R}}}$ \\
Where: \\
$R_{U R}^{2}=R$-squared from Equation (6) \\
$R_{R}^{2}=R$-squared from Equation (5) \\
$n=$ Number of observations \\
$p_{U R}=$ Number of parameters in Equation $(6)=6$ \\
$p_{R}=$ Number of parameters in Equation $(5)=3$ \\
\hline
\end{tabular}


Table 2: Summary Statistics

This table contains summary statistics. 
Table 1 contains the variable definitions.

\begin{tabular}{|c|c|c|c|c|c|}
\hline Variable & Mean & Median & $\begin{array}{c}\text { Standard } \\
\text { Deviation }\end{array}$ & Minimum & Maximum \\
\hline $\ln (\$$ Volume Ratio +1) & 2.596 & 2.336 & 2.206 & 0.000 & 7.773 \\
\hline \multicolumn{6}{|l|}{ Governance Variables } \\
\hline WB Governance Index & 0.806 & 0.857 & 0.158 & 0.294 & 0.994 \\
\hline S\&P Rating & 16.897 & 19.000 & 4.083 & 0.000 & 20.000 \\
\hline ICRG Composite Index & 0.798 & 0.811 & 0.066 & 0.519 & 0.923 \\
\hline Spamann ADRI & 3.929 & 4.000 & 0.908 & 2.000 & 5.000 \\
\hline Rules Index & 1.446 & 1.429 & 0.742 & 0.000 & 3.286 \\
\hline Price Manipulation & 2.607 & 2.000 & 2.131 & 0.000 & 7.000 \\
\hline Volume Manipulation & 0.667 & 0.000 & 0.817 & 0.000 & 2.000 \\
\hline Spoofing & 1.342 & 1.000 & 0.964 & 0.000 & 3.000 \\
\hline False Disclosure & 0.627 & 1.000 & 0.496 & 0.000 & 2.000 \\
\hline Market Manipulation & 3.139 & 2.000 & 2.044 & 0.000 & 9.000 \\
\hline Insider Trading & 1.460 & 2.000 & 0.990 & 0.000 & 4.000 \\
\hline Broker & 0.277 & 0.000 & 0.637 & 0.000 & 3.000 \\
\hline \multicolumn{6}{|l|}{ Control Variables } \\
\hline Exchange $\ln (\$$ Volume Ratio +1$)$ & 0.438 & 0.236 & 0.538 & 0.000 & 2.306 \\
\hline $\ln$ (Assets) & 8.316 & 8.427 & 2.247 & 1.233 & 14.517 \\
\hline Debt/Assets & 0.188 & 0.170 & 0.159 & 0.000 & 1.255 \\
\hline Cash/Assets & 0.109 & 0.058 & 0.144 & 0.000 & 0.976 \\
\hline $\mathrm{R} \& \mathrm{D} /$ Sales & 1.063 & 0.002 & 38.040 & 0.000 & 2100.500 \\
\hline Intangibles/Assets & 0.119 & 0.052 & 0.155 & -0.005 & 0.933 \\
\hline Advertising/Sales & 0.010 & 0.000 & 0.054 & 0.000 & 2.359 \\
\hline High Tech & 0.266 & 0.000 & 0.442 & 0.000 & 1.000 \\
\hline FCF/Assets & 0.005 & 0.028 & 0.146 & -2.777 & 0.554 \\
\hline Information share & 3.353 & 1.804 & 3.844 & 0.155 & 14.415 \\
\hline Trade Imbalance & -0.013 & -0.011 & 0.070 & -0.369 & 0.203 \\
\hline FDI/GDP & 0.000 & 0.000 & 0.001 & -0.002 & 0.004 \\
\hline MKTCAP/GDP & 0.011 & 0.009 & 0.007 & 0.001 & 0.056 \\
\hline Home Turnover & 0.882 & 0.784 & 0.560 & 0.022 & 3.803 \\
\hline Corporate Tax & 0.312 & 0.310 & 0.069 & 0.125 & 0.480 \\
\hline
\end{tabular}


Table 3: Governance Indexes by Year

The Table contains the governance indexes by year. The values are averages for each year.

\begin{tabular}{ccccccc}
\hline Year & $\begin{array}{c}\text { WB } \\
\text { Governance } \\
\text { Index }\end{array}$ & $\begin{array}{c}\text { S\&P } \\
\text { Rating }\end{array}$ & $\begin{array}{c}\text { ICRG } \\
\text { Composite } \\
\text { Index }\end{array}$ & $\begin{array}{c}\text { Spamann } \\
\text { ADRI }\end{array}$ & $\begin{array}{c}\text { Rules Index } \\
\text { (Pre MIFID coding ) }\end{array}$ & $\begin{array}{c}\text { Rules Index } \\
\text { (Post MIFID coding) }\end{array}$ \\
\hline 1999 & 0.828 & 17.241 & 0.786 & 3.996 & 1.494 & 1.873 \\
2000 & 0.842 & 17.457 & 0.805 & 4.003 & 1.476 & 1.906 \\
2001 & 0.840 & 17.341 & 0.813 & 3.954 & 1.456 & 1.902 \\
2002 & 0.819 & 17.054 & 0.800 & 3.938 & 1.432 & 1.888 \\
2003 & 0.812 & 16.954 & 0.802 & 3.932 & 1.442 & 1.880 \\
2004 & 0.799 & 16.598 & 0.802 & 3.946 & 1.446 & 1.836 \\
2005 & 0.796 & 16.813 & 0.798 & 3.904 & 1.408 & 1.781 \\
2006 & 0.794 & 16.813 & 0.795 & 3.890 & 1.355 & 1.653 \\
2007 & 0.754 & 16.094 & 0.790 & 3.860 & 1.313 & 1.665 \\
2008 & 0.749 & 16.324 & 0.775 & 3.839 & 1.301 & \\
\hline
\end{tabular}


Table 4: Governance Variables by Country

This table contains the governance index by country.

Table 1 contains the variable definitions.

\begin{tabular}{|c|c|c|c|c|c|c|c|c|c|c|c|c|c|c|}
\hline Country & $\begin{array}{l}\text { Country } \\
\text { Code }\end{array}$ & $\begin{array}{c}\ln (\$ \text { Volume } \\
\text { Ratio +1) }\end{array}$ & $\begin{array}{l}\text { WB Governance } \\
\text { Index }\end{array}$ & $\begin{array}{c}\text { S\&P } \\
\text { Rating }\end{array}$ & $\begin{array}{c}\text { ICRG } \\
\text { Composite } \\
\text { Index } \\
\end{array}$ & $\begin{array}{c}\text { Spamann } \\
\text { ADRI }\end{array}$ & $\begin{array}{l}\text { Rules } \\
\text { Index }\end{array}$ & $\begin{array}{c}\text { Price } \\
\text { Manipulation }\end{array}$ & $\begin{array}{c}\text { Volume } \\
\text { Manipulation }\end{array}$ & Spoofing & $\begin{array}{c}\text { False } \\
\text { Disclosure }\end{array}$ & $\begin{array}{c}\text { Market } \\
\text { Manipulation }\end{array}$ & $\begin{array}{l}\text { Insider } \\
\text { Trading }\end{array}$ & Brokel \\
\hline Argentina & ARG & 0.910 & 0.45 & 4.35 & 0.68 & 3 & 1.43 & 2.00 & 0.00 & 1.00 & 0.00 & 3.00 & 3.00 & 1.00 \\
\hline Australia & AUS & 3.257 & 0.93 & 19.58 & 0.82 & 4 & 2.00 & 3.00 & 1.00 & 2.00 & 0.00 & 6.00 & 2.00 & 0.00 \\
\hline Austria & AUT & 4.958 & 0.93 & 20.00 & 0.85 & 4 & 0.29 & 1.00 & 0.00 & 0.00 & 0.00 & 1.00 & 0.00 & 0.00 \\
\hline Belgium & BEL & 2.661 & 0.89 & 19.00 & 0.84 & 2 & 1.51 & 3.36 & 0.09 & 1.18 & 1.09 & 4.64 & 0.18 & 0.00 \\
\hline Brazil & BRA & 3.155 & 0.52 & 8.60 & 0.68 & 5 & 0.45 & 0.05 & 0.00 & 1.00 & 0.00 & 1.05 & 1.05 & 0.03 \\
\hline Canada & CAN & 0.010 & 0.93 & 20.00 & 0.86 & 4 & 2.00 & 3.00 & 1.00 & 2.00 & 0.00 & 6.00 & 2.00 & 0.00 \\
\hline Switzerland & CHE & 2.679 & 0.97 & 20.00 & 0.90 & 3 & 1.74 & 2.60 & 0.83 & 1.29 & 0.95 & 4.13 & 1.73 & 0.67 \\
\hline Chile & $\mathrm{CHL}$ & 1.939 & 0.84 & 14.50 & 0.77 & 5 & 0.00 & 0.00 & 0.00 & 0.00 & 0.00 & 0.00 & 0.00 & 0.00 \\
\hline Spain & ESP & 2.480 & 0.83 & 19.36 & 0.79 & 5 & 1.23 & 0.88 & 0.05 & 1.09 & 0.60 & 2.11 & 3.46 & 0.40 \\
\hline Finland & FIN & 0.013 & 0.99 & 19.61 & 0.88 & 4 & 1.10 & 1.23 & 0.20 & 1.07 & 0.37 & 2.50 & 1.70 & 0.63 \\
\hline France & FRA & 3.578 & 0.85 & 20.00 & 0.79 & 5 & 1.43 & 3.04 & 0.05 & 1.10 & 0.99 & 4.57 & 0.22 & 0.06 \\
\hline United Kingdom & GBR & 3.577 & 0.91 & 20.00 & 0.82 & 4 & 2.13 & 5.39 & 1.75 & 2.72 & 0.89 & 2.10 & 2.03 & 0.06 \\
\hline Greece & GRC & 1.715 & 0.72 & 14.97 & 0.74 & 3 & 1.60 & 2.64 & 0.45 & 1.52 & 0.71 & 3.76 & 1.93 & 0.19 \\
\hline Hong Kong & HKG & 2.392 & 0.84 & 16.31 & 0.83 & 4 & 1.84 & 2.67 & 1.71 & 1.06 & 0.84 & 6.16 & 0.35 & 0.12 \\
\hline India & IND & 1.640 & 0.47 & 9.78 & 0.69 & 4 & 1.57 & 0.00 & 1.00 & 1.00 & 1.00 & 3.00 & 2.00 & 3.00 \\
\hline Ireland & IRL & 1.555 & 0.93 & 19.68 & 0.86 & 4 & 1.34 & 3.36 & 0.85 & 1.90 & 0.45 & 1.90 & 0.95 & 0.00 \\
\hline Israel & ISR & 0.996 & 0.67 & 14.17 & 0.71 & 3 & 1.01 & 1.98 & 0.04 & 0.14 & 0.94 & 2.84 & 1.10 & 0.07 \\
\hline Italy & ITA & 3.903 & 0.74 & 17.52 & 0.79 & 2 & 0.83 & 0.51 & 0.04 & 1.07 & 0.88 & 2.10 & 1.11 & 0.12 \\
\hline Japan & JPN & 3.892 & 0.84 & 17.92 & 0.84 & 5 & 0.74 & 0.97 & 0.01 & 1.02 & 0.02 & 1.92 & 1.12 & 0.11 \\
\hline Korea & KOR & 2.342 & 0.70 & 13.76 & 0.80 & 4 & 3.29 & 4.00 & 2.00 & 2.00 & 1.00 & 9.00 & 3.00 & 2.00 \\
\hline Mexico & MEX & 1.895 & 0.51 & 11.00 & 0.73 & 2 & 2.00 & 3.02 & 1.00 & 1.01 & 1.00 & 5.97 & 2.01 & 0.00 \\
\hline Netherlands & NLD & 2.214 & 0.96 & 20.00 & 0.86 & 4 & 1.31 & 2.38 & 0.20 & 1.16 & 0.70 & 3.54 & 0.88 & 0.32 \\
\hline
\end{tabular}




\begin{tabular}{|c|c|c|c|c|c|c|c|c|c|c|c|c|c|c|}
\hline Norway & NOR & 3.618 & 0.95 & 20.00 & 0.91 & 4 & 1.48 & 2.00 & 0.77 & 1.04 & 0.14 & 3.75 & 2.54 & 0.11 \\
\hline New Zealand & NZL & 2.452 & 0.96 & 19.00 & 0.79 & 5 & 2.00 & 2.46 & 0.46 & 1.46 & 0.54 & 4.92 & 2.54 & 1.62 \\
\hline Philippines & PHL & 0.590 & 0.40 & 8.85 & 0.69 & 4 & 0.00 & 0.00 & 0.00 & 0.00 & 0.00 & 0.00 & 0.00 & 0.00 \\
\hline Portugal & PRT & 0.078 & 0.85 & 17.49 & 0.78 & 3 & 0.94 & 1.00 & 0.14 & 1.29 & 0.14 & 1.00 & 2.14 & 0.86 \\
\hline Singapore & SGP & 2.467 & 0.88 & 20.00 & 0.89 & 4 & 2.57 & 3.00 & 1.00 & 2.00 & 1.00 & 7.00 & 2.00 & 2.00 \\
\hline Sweden & SWE & 0.027 & 0.97 & 19.19 & 0.85 & 4 & 1.03 & 1.17 & 0.10 & 1.07 & 0.37 & 2.33 & 1.50 & 0.70 \\
\hline Turkey & TUR & 1.556 & 0.48 & 6.92 & 0.61 & 4 & 0.00 & 0.00 & 0.00 & 0.00 & 0.00 & 0.00 & 0.00 & 0.00 \\
\hline South Africa & ZAF & 0.009 & 0.63 & 11.82 & 0.71 & 5 & 1.87 & 3.65 & 1.18 & 2.10 & 0.53 & 3.22 & 2.10 & 0.33 \\
\hline
\end{tabular}

\section{Table 5: Correlation Statistics}

The table contains pairwise correlation statistics. Brackets contain p-values.

\begin{tabular}{|c|c|c|c|c|c|c|c|c|c|c|c|c|c|}
\hline & Variable & $\mathrm{A}$ & B & $\mathrm{C}$ & $\mathrm{D}$ & $\mathrm{E}$ & $\mathrm{F}$ & $\mathrm{G}$ & $\mathrm{H}$ & I & $\mathrm{J}$ & $\mathrm{K}$ & $\mathrm{L}$ \\
\hline $\mathrm{A}$ & \$Volume Ratio & & & & & & & & & & & & \\
\hline \multirow[t]{2}{*}{ B } & WB Governance Index & 0.04 & & & & & & & & & & & \\
\hline & & {$[0.02]$} & & & & & & & & & & & \\
\hline \multirow[t]{2}{*}{$\mathrm{C}$} & S\&P Rating & 0.04 & 0.92 & & & & & & & & & & \\
\hline & & {$[0.01]$} & {$[0.00]$} & & & & & & & & & & \\
\hline \multirow[t]{2}{*}{$\mathrm{D}$} & ICRG Composite Index & 0.06 & 0.84 & 0.81 & & & & & & & & & \\
\hline & & {$[0.00]$} & {$[0.00]$} & {$[0.00]$} & & & & & & & & & \\
\hline \multirow[t]{2}{*}{$\mathrm{E}$} & Spamann ADRI & 0.12 & 0.39 & 0.30 & 0.24 & & & & & & & & \\
\hline & & {$[0.00]$} & {$[0.00]$} & {$[0.00]$} & {$[0.00]$} & & & & & & & & \\
\hline \multirow[t]{2}{*}{$\mathrm{F}$} & Rules Index & 0.02 & 0.11 & 0.20 & 0.16 & -0.26 & & & & & & & \\
\hline & & {$[0.26]$} & {$[0.00]$} & {$[0.00]$} & {$[0.00]$} & {$[0.00]$} & & & & & & & \\
\hline \multirow[t]{2}{*}{$\mathrm{G}$} & Price Manipulation & 0.04 & 0.25 & 0.33 & 0.18 & -0.12 & 0.84 & & & & & & \\
\hline & & {$[0.03]$} & {$[0.00]$} & {$[0.00]$} & {$[0.00]$} & {$[0.00]$} & {$[0.00]$} & & & & & & \\
\hline \multirow[t]{2}{*}{$\mathrm{H}$} & Volume Manipulation & 0.07 & 0.17 & 0.21 & 0.20 & -0.13 & 0.84 & 0.80 & & & & & \\
\hline & & {$[0.00]$} & {$[0.00]$} & {$[0.00]$} & {$[0.00]$} & {$[0.00]$} & {$[0.00]$} & {$[0.00]$} & & & & & \\
\hline \multirow[t]{2}{*}{ I } & Spoofing & 0.12 & 0.34 & 0.40 & 0.32 & 0.06 & 0.76 & 0.84 & 0.82 & & & & \\
\hline & & {$[0.00]$} & {$[0.00]$} & {$[0.00]$} & {$[0.00]$} & {$[0.00]$} & {$[0.00]$} & {$[0.00]$} & {$[0.00]$} & & & & \\
\hline \multirow[t]{2}{*}{$\mathrm{J}$} & False Disclosure & -0.03 & -0.01 & 0.15 & -0.03 & -0.39 & 0.61 & 0.61 & 0.44 & 0.31 & & & \\
\hline & & {$[0.10]$} & {$[0.51]$} & {$[0.00]$} & {$[0.05]$} & {$[0.00]$} & {$[0.00]$} & {$[0.00]$} & {$[0.00]$} & {$[0.00]$} & & & \\
\hline $\mathrm{K}$ & Market Manipulation & -0.04 & -0.09 & -0.03 & 0.04 & -0.31 & 0.54 & 0.18 & 0.20 & -0.03 & 0.35 & & \\
\hline
\end{tabular}




\begin{tabular}{cccccccccccc}
{$[0.02]$} & {$[0.00]$} & {$[0.15]$} & {$[0.01]$} & {$[0.00]$} & {$[0.00]$} & {$[0.00]$} & {$[0.00]$} & {$[0.15]$} & {$[0.00]$} & & \\
0.01 & -0.11 & -0.07 & -0.03 & -0.22 & 0.52 & 0.29 & 0.44 & 0.49 & 0.03 & 0.00 & \\
{$[0.53]$} & {$[0.00]$} & {$[0.00]$} & {$[0.10]$} & {$[0.00]$} & {$[0.00]$} & {$[0.00]$} & {$[0.00]$} & {$[0.00]$} & {$[0.14]$} & {$[0.91]$} & \\
-0.10 & -0.18 & -0.21 & -0.08 & -0.01 & 0.11 & -0.26 & -0.02 & -0.07 & -0.03 & 0.11 & 0.37 \\
{$[0.00]$} & {$[0.00]$} & {$[0.00]$} & {$[0.00]$} & {$[0.73]$} & {$[0.00]$} & {$[0.00]$} & {$[0.32]$} & {$[0.00]$} & {$[0.05]$} & {$[0.00]$} & {$[0.00]$} \\
\hline
\end{tabular}


Table 6: Governance Analysis

This table analyzes the relationship between sovereign governance and the ratio of non-U.S. volume to U.S.-volume. 
Table 1 contains the variable definitions. All models include year and exchange dummies and cluster standard errors by firm. Brackets contain p-values. Superscripts ${ }^{* * *},{ }^{* *}$, and ${ }^{*}$ denote significance at $1 \%, 5 \%$, and $10 \%$, respectively.

\begin{tabular}{|c|c|c|c|c|}
\hline \multirow{3}{*}{$\begin{array}{l}\text { Dependent Variable } \\
\text { Model } \\
\text { Column }\end{array}$} & \multicolumn{4}{|c|}{$\ln ($ \$Volume Ratio +1) } \\
\hline & Tob & ummies, Ex & ummies, Fi & ring \\
\hline & [1] & [2] & [3] & [4] \\
\hline WB Governance Index & $\begin{array}{c}2.513^{*} \\
{[0.054]}\end{array}$ & & & \\
\hline S\&P Rating & & $\begin{array}{c}0.140 * * * \\
{[0.002]}\end{array}$ & & \\
\hline ICRG Composite Index & & & $\begin{array}{c}5.189 * * \\
{[0.010]}\end{array}$ & \\
\hline ADRI (Spamann) & & & & $\begin{array}{c}-0.053 \\
{[0.795]}\end{array}$ \\
\hline Exchange $\ln (\$$ Volume Ratio +1) & $\begin{array}{c}0.12 \\
{[0.605]}\end{array}$ & $\begin{array}{c}0.118 \\
{[0.614]}\end{array}$ & $\begin{array}{c}0.115 \\
{[0.624]}\end{array}$ & $\begin{array}{c}0.137 \\
{[0.557]}\end{array}$ \\
\hline US Institutional Holdings & $\begin{array}{c}-3.195 * * * \\
{[0.000]}\end{array}$ & $\begin{array}{c}-3.126 * * * \\
{[0.000]}\end{array}$ & $\begin{array}{c}-3.187 * * * \\
{[0.000]}\end{array}$ & $\begin{array}{c}-3.255 * * * \\
{[0.000]}\end{array}$ \\
\hline $\ln$ (Assets) & $\begin{array}{c}-0.102^{* *} \\
{[0.020]}\end{array}$ & $\begin{array}{c}-0.118 * * * \\
{[0.008]}\end{array}$ & $\begin{array}{c}-0.105^{* *} \\
{[0.017]}\end{array}$ & $\begin{array}{c}-0.089 * * \\
{[0.045]}\end{array}$ \\
\hline Debt/Assets & $\begin{array}{c}1.135 * * * \\
{[0.006]}\end{array}$ & $\begin{array}{c}1.120 * * * \\
{[0.006]}\end{array}$ & $\begin{array}{c}1.151^{* * *} \\
{[0.005]}\end{array}$ & $\begin{array}{c}1.142^{* * *} * \\
{[0.005]}\end{array}$ \\
\hline Cash/Assets & $\begin{array}{c}-1.124^{* *} \\
{[0.025]}\end{array}$ & $\begin{array}{c}-1.309 * * * \\
{[0.009]}\end{array}$ & $\begin{array}{c}-1.167 * * \\
{[0.020]}\end{array}$ & $\begin{array}{c}-1.024 * * \\
{[0.042]}\end{array}$ \\
\hline R\&D/Sales & $\begin{array}{c}0.083 \\
{[0.275]}\end{array}$ & $\begin{array}{c}0.074 \\
{[0.338]}\end{array}$ & $\begin{array}{c}0.091 \\
{[0.240]}\end{array}$ & $\begin{array}{c}0.099 \\
{[0.207]}\end{array}$ \\
\hline Intangibles/Assets & $\begin{array}{c}0.404 \\
{[0.399]}\end{array}$ & $\begin{array}{c}0.304 \\
{[0.523]}\end{array}$ & $\begin{array}{c}0.386 \\
{[0.422]}\end{array}$ & $\begin{array}{c}0.396 \\
{[0.411]}\end{array}$ \\
\hline Advertising/Sales & $\begin{array}{c}1.303 \\
{[0.158]}\end{array}$ & $\begin{array}{c}1.272 \\
{[0.168]}\end{array}$ & $\begin{array}{c}1.261 \\
{[0.175]}\end{array}$ & $\begin{array}{c}1.359 \\
{[0.140]}\end{array}$ \\
\hline I(High Tech) & $\begin{array}{c}0.124 \\
{[0.530]}\end{array}$ & $\begin{array}{c}0.144 \\
{[0.461]}\end{array}$ & $\begin{array}{c}0.14 \\
{[0.475]}\end{array}$ & $\begin{array}{c}0.143 \\
{[0.463]}\end{array}$ \\
\hline FCF/Assets & $\begin{array}{c}0.908 * * \\
{[0.025]}\end{array}$ & $\begin{array}{c}0.889 * * \\
{[0.030]}\end{array}$ & $\begin{array}{l}0.931 * * \\
{[0.023]}\end{array}$ & $\begin{array}{c}0.946^{* *} \\
{[0.018]}\end{array}$ \\
\hline Trade Imbalance & $\begin{array}{c}0.45 \\
{[0.758]}\end{array}$ & $\begin{array}{c}-0.602 \\
{[0.688]}\end{array}$ & $\begin{array}{c}1.276 \\
{[0.376]}\end{array}$ & $\begin{array}{c}0.285 \\
{[0.847]}\end{array}$ \\
\hline FDI/GDP & $\begin{array}{c}104.53 \\
{[0.351]}\end{array}$ & $\begin{array}{l}120.259 \\
{[0.281]}\end{array}$ & $\begin{array}{c}101.65 \\
{[0.376]}\end{array}$ & $\begin{array}{l}121.393 \\
{[0.298]}\end{array}$ \\
\hline Home Market Cap/GDP & $\begin{array}{c}-36.605^{*} \\
{[0.082]}\end{array}$ & $\begin{array}{l}-32.709 \\
{[0.106]}\end{array}$ & $\begin{array}{c}-38.941 * \\
{[0.067]}\end{array}$ & $\begin{array}{l}-33.117 \\
{[0.114]}\end{array}$ \\
\hline Home Market Turnover & $\begin{array}{c}-0.309 * * \\
{[0.030]}\end{array}$ & $\begin{array}{c}-0.339 * * \\
{[0.017]}\end{array}$ & $\begin{array}{c}-0.21 \\
{[0.150]}\end{array}$ & $\begin{array}{c}-0.127 \\
{[0.426]}\end{array}$ \\
\hline $\ln$ (Distance from NY km) & $\begin{array}{c}0.581 \\
{[0.780]}\end{array}$ & $\begin{array}{c}0.753 \\
{[0.731]}\end{array}$ & $\begin{array}{c}0.385 \\
{[0.867]}\end{array}$ & $\begin{array}{c}0.354 \\
{[0.864]}\end{array}$ \\
\hline abs(Time Zone Difference) & $\begin{array}{c}-0.624 \\
{[0.320]}\end{array}$ & $\begin{array}{c}-0.682 \\
{[0.286]}\end{array}$ & $\begin{array}{c}-0.506 \\
{[0.454]}\end{array}$ & $\begin{array}{c}-0.554 \\
{[0.377]}\end{array}$ \\
\hline I(Same Language) & $\begin{array}{c}2.502 \\
{[0.353]}\end{array}$ & $\begin{array}{c}2.652 \\
{[0.338]}\end{array}$ & $\begin{array}{c}1.666 \\
{[0.547]}\end{array}$ & $\begin{array}{c}2.121 \\
{[0.432]}\end{array}$ \\
\hline Corp Tax Rate & $\begin{array}{c}0.533 \\
{[0.811]}\end{array}$ & $\begin{array}{c}0.802 \\
{[0.722]}\end{array}$ & $\begin{array}{c}0.282 \\
{[0.901]}\end{array}$ & $\begin{array}{c}-1.008 \\
{[0.693]}\end{array}$ \\
\hline Constant & $\begin{array}{c}0.552 \\
{[0.972]}\end{array}$ & $\begin{array}{l}-1.211 \\
{[0.942]}\end{array}$ & $\begin{array}{c}-0.482 \\
{[0.978]}\end{array}$ & $\begin{array}{c}4.55 \\
{[0.768]}\end{array}$ \\
\hline
\end{tabular}


Observations

Pseudo R-squared

F-statistic
3,128

$13.02 \%$

3578
3,128

$13.27 \%$

3728
3,128

$13.08 \%$

3605
3,128

$12.88 \%$

3689 


\section{Table 7: Exchange Rule Analysis}

This table contains tobit regressions that analyze the relationship between stock-exchange rules and the ratio of non-U.S. volume to U.S. volume. 
Table 1 contains the variable definitions. Brackets contain p-values. Superscripts ***, ${ }^{* *}$, and ${ }^{*}$ denote significance at $1 \%, 5 \%$, and $10 \%$, respectively.

\begin{tabular}{|c|c|c|c|c|c|c|c|c|}
\hline \multirow{3}{*}{$\begin{array}{l}\text { Dependent Variable } \\
\text { Model } \\
\text { Rules Variable }\end{array}$} & \multicolumn{8}{|c|}{$\ln (\$$ Volume Ratio+1) } \\
\hline & \multirow[b]{2}{*}{$\begin{array}{c}\text { Rules Index } \\
\text { [1] }\end{array}$} & \multicolumn{6}{|c|}{ Tobit, Year Dummies, Exchange Dummies, Firm Clustering } & \multirow[b]{2}{*}{$\begin{array}{c}\text { Broker } \\
\text { [8] }\end{array}$} \\
\hline & & $\begin{array}{c}\text { Price Manipulation } \\
\text { [2] }\end{array}$ & $\begin{array}{c}\text { Volume Manipulation } \\
\text { [3] }\end{array}$ & $\begin{array}{c}\text { Spoofing } \\
{[4]}\end{array}$ & $\begin{array}{c}\text { False Disclosure } \\
\text { [5] } \\
\end{array}$ & $\begin{array}{c}\text { Market Manipulation } \\
\text { [6] }\end{array}$ & $\begin{array}{c}\text { Insider Trading } \\
\text { [7] }\end{array}$ & \\
\hline \multirow[t]{2}{*}{ Rules Variable } & $4.747 * * *$ & $0.744 * * *$ & -1.737 & 0.568 & $1.498^{* * *}$ & $2.136^{* * *}$ & 0.185 & -4.85 \\
\hline & {$[0.000]$} & {$[0.000]$} & {$[0.580]$} & [0.647] & {$[0.000]$} & {$[0.000]$} & {$[0.377]$} & {$[0.123]$} \\
\hline \multirow[t]{2}{*}{ Rules Variable Squared } & $-1.430 * * *$ & $-0.092 * * *$ & 2.229 & -0.098 & $-0.492 * * *$ & $-0.336 * * *$ & $-0.119 *$ & 3.789 \\
\hline & {$[0.000]$} & {$[0.000]$} & [0.473] & [0.754] & {$[0.000]$} & {$[0.000]$} & [0.068] & {$[0.226]$} \\
\hline \multirow[t]{2}{*}{ Exchange $\ln (\$$ Volume Ratio+1) } & 0.109 & 0.102 & 0.119 & 0.12 & 0.109 & 0.095 & 0.128 & 0.116 \\
\hline & {$[0.638]$} & {$[0.661]$} & {$[0.610]$} & {$[0.606]$} & [0.639] & [0.687] & {$[0.584]$} & {$[0.619]$} \\
\hline \multirow[t]{2}{*}{ US Institutional Holdings } & $-3.301^{* * *}$ & $-3.284 * * *$ & $-3.263 * * *$ & $-3.260^{* * *}$ & $-3.301^{* * *}$ & $-3.252 * * *$ & $-3.233 * * *$ & $-3.295^{* * *}$ \\
\hline & {$[0.000]$} & {$[0.000]$} & {$[0.000]$} & {$[0.000]$} & {$[0.000]$} & {$[0.000]$} & {$[0.000]$} & {$[0.000]$} \\
\hline \multirow[t]{2}{*}{$\ln$ (Assets) } & $-0.089^{* *}$ & $-0.090 * *$ & $-0.090^{* *}$ & $-0.090^{* *}$ & $-0.089 * *$ & $-0.091^{* *}$ & $-0.091^{* *}$ & $-0.089 * *$ \\
\hline & {$[0.042]$} & {$[0.041]$} & {$[0.041]$} & {$[0.040]$} & {$[0.042]$} & {$[0.038]$} & [0.038] & {$[0.043]$} \\
\hline \multirow[t]{2}{*}{ Debt/Assets } & $1.109 * * *$ & $1.117^{* * *}$ & $1.137 * * *$ & $1.141^{* * *}$ & $1.125^{* * *}$ & $1.158^{* * *}$ & $1.148^{* * *}$ & $1.128 * * *$ \\
\hline & {$[0.006]$} & {$[0.006]$} & {$[0.005]$} & {$[0.005]$} & {$[0.006]$} & {$[0.004]$} & {$[0.005]$} & {$[0.005]$} \\
\hline \multirow[t]{2}{*}{ Cash/Assets } & $-1.014 * *$ & $-1.024 * *$ & $-1.020 * *$ & $-1.026^{* *}$ & $-1.014 * *$ & $-1.033^{* *}$ & $-1.048^{* *}$ & $-1.011 * *$ \\
\hline & {$[0.044]$} & {$[0.042]$} & {$[0.044]$} & {$[0.043]$} & {$[0.045]$} & {$[0.041]$} & {$[0.038]$} & {$[0.045]$} \\
\hline \multirow[t]{2}{*}{ R\&D/Sales } & 0.095 & 0.095 & 0.099 & 0.099 & 0.097 & 0.097 & 0.099 & 0.097 \\
\hline & {$[0.228]$} & {$[0.227]$} & [0.213] & {$[0.211]$} & [0.222] & [0.207] & [0.203] & {$[0.220]$} \\
\hline \multirow[t]{2}{*}{ Intangibles/Assets } & 0.394 & 0.389 & 0.394 & 0.396 & 0.396 & 0.398 & 0.402 & 0.387 \\
\hline & {$[0.410]$} & {$[0.418]$} & [0.413] & {$[0.410]$} & [0.409] & {$[0.408]$} & {$[0.404]$} & {$[0.420]$} \\
\hline \multirow[t]{2}{*}{ Advertising/Sales } & 1.369 & 1.358 & 1.355 & 1.355 & 1.37 & 1.354 & 1.35 & 1.369 \\
\hline & {$[0.141]$} & [0.144] & {$[0.142]$} & [0.142] & {$[0.140]$} & {$[0.140]$} & {$[0.141]$} & {$[0.141]$} \\
\hline \multirow[t]{2}{*}{ I(High Tech) } & 0.142 & 0.143 & 0.14 & 0.141 & 0.143 & 0.143 & 0.142 & 0.142 \\
\hline & {$[0.465]$} & {$[0.460]$} & {$[0.472]$} & {$[0.468]$} & {$[0.461]$} & {$[0.462]$} & {$[0.466]$} & {$[0.463]$} \\
\hline \multirow[t]{2}{*}{ FCF/Assets } & $0.920^{* *}$ & $0.922 * *$ & $0.926^{* *}$ & $0.930^{* *}$ & $0.910^{* *}$ & $0.963^{* *}$ & $0.958^{* *}$ & $0.912^{* *}$ \\
\hline & {$[0.020]$} & {$[0.020]$} & {$[0.021]$} & {$[0.020]$} & {$[0.023]$} & {$[0.015]$} & {$[0.016]$} & {$[0.022]$} \\
\hline \multirow[t]{2}{*}{ Trade Imbalance } & 0.197 & 0.158 & 0.251 & 0.27 & 0.209 & 0.115 & 0.265 & 0.183 \\
\hline & [0.894] & [0.915] & [0.865] & [0.855] & [0.887] & [0.938] & {$[0.858]$} & {$[0.902]$} \\
\hline
\end{tabular}




\begin{tabular}{|c|c|c|c|c|c|c|c|c|}
\hline \multirow[t]{2}{*}{ FDI/GDP } & 142.649 & 120.245 & 142.288 & 138.54 & 149.284 & 88.206 & 111.221 & 135.304 \\
\hline & {$[0.212]$} & {$[0.299]$} & {$[0.216]$} & {$[0.227]$} & {$[0.195]$} & {$[0.447]$} & {$[0.332]$} & {$[0.243]$} \\
\hline \multirow[t]{2}{*}{ Home Market Cap/GDP } & -34.418 & -34.481 & -33.098 & -33.133 & -33.267 & $-35.198 *$ & -34.265 & -33.047 \\
\hline & {$[0.101]$} & {$[0.101]$} & {$[0.115]$} & {$[0.115]$} & {$[0.113]$} & [0.094] & {$[0.103]$} & {$[0.116]$} \\
\hline \multirow[t]{2}{*}{ Home Market Turnover } & -0.124 & -0.112 & -0.14 & -0.14 & -0.135 & -0.066 & -0.107 & -0.13 \\
\hline & {$[0.425]$} & {$[0.475]$} & [0.367] & {$[0.367]$} & {$[0.382]$} & {$[0.677]$} & {$[0.499]$} & {$[0.403]$} \\
\hline \multirow[t]{2}{*}{ ln(Distance from NY km) } & 0.828 & 0.561 & 0.494 & 0.253 & 0.456 & 0.451 & 0.541 & 0.45 \\
\hline & {$[0.745]$} & {$[0.807]$} & {$[0.820]$} & {$[0.898]$} & {$[0.834]$} & {$[0.835]$} & {$[0.808]$} & [0.835] \\
\hline \multirow[t]{2}{*}{ abs(Time Zone Difference) } & -0.482 & -0.529 & -0.558 & -0.601 & -0.554 & -0.536 & -0.535 & -0.56 \\
\hline & {$[0.520]$} & {$[0.446]$} & {$[0.390]$} & [0.329] & [0.399] & {$[0.416]$} & {$[0.423]$} & [0.392] \\
\hline \multirow[t]{2}{*}{ I(Same Language) } & 2.341 & 1.776 & 1.546 & 2.242 & 2.024 & $5.743^{*}$ & 1.95 & -3.376 \\
\hline & {$[0.502]$} & {$[0.571]$} & [0.587] & {$[0.374]$} & {$[0.483]$} & {$[0.053]$} & [0.515] & [0.380] \\
\hline \multirow[t]{2}{*}{ Corp Tax Rate } & -0.996 & -1.062 & -1.011 & -1.078 & -0.993 & -1.353 & -1.319 & -1.006 \\
\hline & {$[0.700]$} & {$[0.682]$} & [0.699] & [0.679] & {$[0.702]$} & [0.598] & {$[0.611]$} & [0.698] \\
\hline \multirow[t]{2}{*}{ Constant } & -4.079 & 1.043 & 3.005 & 4.925 & 2.283 & 1.44 & 2.809 & 3.39 \\
\hline & {$[0.834]$} & {$[0.952]$} & {$[0.854]$} & {$[0.742]$} & {$[0.890]$} & [0.929] & {$[0.868]$} & [0.835] \\
\hline Observations & 3,128 & 3,128 & 3,128 & 3,128 & 3,128 & 3,128 & 3,128 & 3,128 \\
\hline F test & $12.96 \%$ & $12.95 \%$ & $12.90 \%$ & $12.89 \%$ & $12.94 \%$ & $12.98 \%$ & $12.89 \%$ & $12.94 \%$ \\
\hline Pseudo R-squared & 3593 & 3614 & 3667 & 3667 & 3558 & 3553 & 3604 & 3574 \\
\hline
\end{tabular}




\section{Table 8: Rules and Governance}

This table contains tobit regressions that analyze both the level of sovereign governance and the stock exchange rules. The tobit regression has a lower bound of zero and includes year and stock-exchange fixedeffects and cluster standard errors by firm. The column title contains the governance variable. The rules variable in each model is the time-varying rules index. Brackets contain p-values. Superscripts ${ }^{* * *}$, ${ }^{* *}$, and ${ }^{*}$ denote significance at $1 \%, 5 \%$, and $10 \%$, respectively.

\begin{tabular}{|c|c|c|c|c|}
\hline \multirow{3}{*}{$\begin{array}{l}\text { Dependent Variable } \\
\text { Model } \\
\text { Column }\end{array}$} & \multicolumn{4}{|c|}{$\ln (\$$ Volume Ratio +1) } \\
\hline & Tobit & ummies, Ex & Dummies, F & tering \\
\hline & {$[1]$} & [2] & [3] & [4] \\
\hline WB Governance Index & $\begin{array}{l}2.567 * * \\
{[0.049]}\end{array}$ & & & \\
\hline WB Governance Index x Rules Index & & $\begin{array}{c}0.145^{* * *} \\
{[0.001]}\end{array}$ & & \\
\hline S\&P Rating & & & $\begin{array}{c}5.279 * * * \\
{[0.009]}\end{array}$ & \\
\hline S\&P Rating $x$ Rules Index & & & & $\begin{array}{c}-0.044 \\
{[0.825]}\end{array}$ \\
\hline Rules Index & $\begin{array}{c}4.534 * * * \\
{[0.000]}\end{array}$ & $\begin{array}{c}4.200 * * * \\
{[0.000]}\end{array}$ & $\begin{array}{c}4.233^{* * *} \\
{[0.000]}\end{array}$ & $\begin{array}{c}4.728 * * * \\
{[0.000]}\end{array}$ \\
\hline Squared Rules Index & $\begin{array}{c}-1.332 * * * \\
{[0.000]}\end{array}$ & $\begin{array}{c}-1.186 * * * \\
{[0.000]}\end{array}$ & $\begin{array}{c}-1.222 * * * \\
{[0.000]}\end{array}$ & $\begin{array}{c}-1.425 * * * \\
{[0.000]}\end{array}$ \\
\hline Exchange $\ln (\$$ Volume Ratio +1) & $\begin{array}{c}0.091 \\
{[0.695]}\end{array}$ & $\begin{array}{c}0.084 \\
{[0.719]}\end{array}$ & $\begin{array}{c}0.084 \\
{[0.719]}\end{array}$ & $\begin{array}{c}0.111 \\
{[0.633]}\end{array}$ \\
\hline US Institutional Holdings & $\begin{array}{c}-3.247 * * * \\
{[0.000]}\end{array}$ & $\begin{array}{c}-3.178 * * * \\
{[0.000]}\end{array}$ & $\begin{array}{c}-3.239 * * * \\
{[0.000]}\end{array}$ & $\begin{array}{c}-3.305 * * * \\
{[0.000]}\end{array}$ \\
\hline $\ln$ (Assets) & $\begin{array}{c}-0.101^{* *} \\
{[0.021]}\end{array}$ & $\begin{array}{c}-0.117 * * * \\
{[0.008]}\end{array}$ & $\begin{array}{c}-0.104^{* *} \\
{[0.018]}\end{array}$ & $\begin{array}{c}-0.088^{* *} \\
{[0.047]}\end{array}$ \\
\hline Debt/Assets & $\begin{array}{c}1.105^{* * *} \\
{[0.007]}\end{array}$ & $\begin{array}{c}1.088 * * * \\
{[0.008]}\end{array}$ & $\begin{array}{c}1.122 * * * \\
{[0.006]}\end{array}$ & $\begin{array}{c}1.111^{* * *} \\
{[0.006]}\end{array}$ \\
\hline Cash/Assets & $\begin{array}{c}-1.097 * * \\
{[0.028]}\end{array}$ & $\begin{array}{c}-1.284 * * \\
{[0.010]}\end{array}$ & $\begin{array}{c}-1.139 * * \\
{[0.022]}\end{array}$ & $\begin{array}{c}-1.002 * * \\
{[0.045]}\end{array}$ \\
\hline R\&D/Sales & $\begin{array}{c}0.079 \\
{[0.304]}\end{array}$ & $\begin{array}{c}0.069 \\
{[0.374]}\end{array}$ & $\begin{array}{c}0.087 \\
{[0.265]}\end{array}$ & $\begin{array}{c}0.095 \\
{[0.228]}\end{array}$ \\
\hline Intangibles/Assets & $\begin{array}{c}0.403 \\
{[0.398]}\end{array}$ & $\begin{array}{c}0.299 \\
{[0.528]}\end{array}$ & $\begin{array}{c}0.384 \\
{[0.422]}\end{array}$ & $\begin{array}{c}0.394 \\
{[0.410]}\end{array}$ \\
\hline Advertising/Sales & $\begin{array}{c}1.313 \\
{[0.159]}\end{array}$ & $\begin{array}{c}1.28 \\
{[0.170]}\end{array}$ & $\begin{array}{c}1.27 \\
{[0.177]}\end{array}$ & $\begin{array}{c}1.371 \\
{[0.141]}\end{array}$ \\
\hline I(High Tech) & $\begin{array}{c}0.124 \\
{[0.531]}\end{array}$ & $\begin{array}{c}0.144 \\
{[0.461]}\end{array}$ & $\begin{array}{c}0.14 \\
{[0.475]}\end{array}$ & $\begin{array}{c}0.143 \\
{[0.462]}\end{array}$ \\
\hline FCF/Assets & $\begin{array}{c}0.882 * * \\
{[0.029]}\end{array}$ & $\begin{array}{c}0.857 * * \\
{[0.036]}\end{array}$ & $\begin{array}{c}0.904 * * \\
{[0.027]}\end{array}$ & $\begin{array}{c}0.925^{* *} \\
{[0.020]}\end{array}$ \\
\hline Trade Imbalance & $\begin{array}{c}0.351 \\
{[0.810]}\end{array}$ & $\begin{array}{c}-0.738 \\
{[0.621]}\end{array}$ & $\begin{array}{c}1.191 \\
{[0.407]}\end{array}$ & $\begin{array}{c}0.189 \\
{[0.898]}\end{array}$ \\
\hline FDI/GDP & $\begin{array}{l}125.766 \\
{[0.261]}\end{array}$ & $\begin{array}{c}147.71 \\
{[0.184]}\end{array}$ & $\begin{array}{l}125.029 \\
{[0.274]}\end{array}$ & $\begin{array}{l}139.131 \\
{[0.232]}\end{array}$ \\
\hline Home Market Cap/GDP & $\begin{array}{c}-37.444^{*} \\
{[0.075]}\end{array}$ & $\begin{array}{c}-33.21 \\
{[0.100]}\end{array}$ & $\begin{array}{c}-39.666^{*} \\
{[0.062]}\end{array}$ & $\begin{array}{l}-34.115 \\
{[0.103]}\end{array}$ \\
\hline Home Market Turnover & $\begin{array}{c}-0.307 * * \\
{[0.031]}\end{array}$ & $\begin{array}{c}-0.345^{* *} \\
{[0.015]}\end{array}$ & $\begin{array}{c}-0.208 \\
{[0.151]}\end{array}$ & $\begin{array}{c}-0.118 \\
{[0.458]}\end{array}$ \\
\hline ln(Distance from NY km) & $\begin{array}{c}0.981 \\
{[0.692]}\end{array}$ & $\begin{array}{c}1.103 \\
{[0.663]}\end{array}$ & $\begin{array}{c}0.742 \\
{[0.776]}\end{array}$ & $\begin{array}{c}0.795 \\
{[0.751]}\end{array}$ \\
\hline abs(Time Zone Difference) & $\begin{array}{c}-0.543 \\
{[0.451]}\end{array}$ & $\begin{array}{c}-0.616 \\
{[0.388]}\end{array}$ & $\begin{array}{c}-0.431 \\
{[0.554]}\end{array}$ & $\begin{array}{c}-0.466 \\
{[0.525]}\end{array}$ \\
\hline I(Same Language) & $\begin{array}{c}2.53 \\
{[0.449]}\end{array}$ & $\begin{array}{c}2.539 \\
{[0.443]}\end{array}$ & $\begin{array}{c}1.608 \\
{[0.622]}\end{array}$ & $\begin{array}{c}2.266 \\
{[0.508]}\end{array}$ \\
\hline Corp Tax Rate & $\begin{array}{c}0.83 \\
{[0.708]}\end{array}$ & $\begin{array}{c}1.183 \\
{[0.599]}\end{array}$ & $\begin{array}{c}0.587 \\
{[0.795]}\end{array}$ & $\begin{array}{c}-0.829 \\
{[0.745]}\end{array}$ \\
\hline Constant & -7.333 & -8.497 & -7.8 & -3.732 \\
\hline
\end{tabular}


Observations

Pseudo R-squared

$\mathrm{F}$ test
[0.699]

3,128

$13.11 \%$

3453
[0.663]

3,128

$13.37 \%$

3600
[0.696]

3,128

$13.17 \%$

3479
[0.845]

3,128

$12.96 \%$ 
Table 9: Interaction of Rules and Governance

This table focuses on the interaction of the country-level governance variables with the stock exchange variables. The models are Tobit models (with a lower bound of zero) that include year and exchange dummies and cluster standard errors by firm. 
Table 1 contains the variable definitions. Brackets contain p-values. Superscripts ${ }^{* * *}, * *$, and ${ }^{*}$ denote significance at $1 \%, 5 \%$, and $10 \%$, respectively.

\begin{tabular}{|c|c|c|c|c|}
\hline \multirow{3}{*}{$\begin{array}{l}\text { Dependent Variable } \\
\text { Model } \\
\text { Column }\end{array}$} & \multicolumn{4}{|c|}{$\ln (\$$ Volume Ratio +1) } \\
\hline & \multicolumn{4}{|c|}{ Tobit, Year Dummies, Exchange Dummies, Firm Clustering } \\
\hline & [1] & [2] & [3] & [4] \\
\hline WB Governance Index & $\begin{array}{c}-6.087 * * * \\
{[0.000]}\end{array}$ & & & \\
\hline WB Governance Index x Rules Index & $\begin{array}{c}5.498 * * * \\
{[0.000]}\end{array}$ & & & \\
\hline S\&P Rating & & $\begin{array}{c}-0.173 * * \\
{[0.031]}\end{array}$ & & \\
\hline S\&P Rating x Rules Index & & $\begin{array}{c}0.211^{* * *} \\
{[0.000]}\end{array}$ & & \\
\hline ICRG Composite Index & & & $\begin{array}{c}-4.124 \\
{[0.195]}\end{array}$ & \\
\hline ICRG Composite Index x Rules Index & & & $\begin{array}{c}6.679 * * * \\
{[0.005]}\end{array}$ & \\
\hline ADRI (Spamann) & & & & $\begin{array}{c}0.666 * \\
{[0.055]}\end{array}$ \\
\hline ADRI (Spamann) x Rules Index & & & & $\begin{array}{c}-0.509^{*} \\
{[0.074]}\end{array}$ \\
\hline Rules Index & $\begin{array}{c}-4.248 * * * \\
{[0.000]}\end{array}$ & $\begin{array}{c}-3.363 * * * \\
{[0.001]}\end{array}$ & $\begin{array}{c}-4.920 * * \\
{[0.010]}\end{array}$ & $\begin{array}{c}2.284 * * \\
{[0.038]}\end{array}$ \\
\hline Exchange $\ln (\$$ Volume Ratio +1) & $\begin{array}{c}0.079 \\
{[0.731]}\end{array}$ & $\begin{array}{l}-0.006 \\
{[0.980]}\end{array}$ & $\begin{array}{c}0.042 \\
{[0.855]}\end{array}$ & $\begin{array}{c}0.122 \\
{[0.597]}\end{array}$ \\
\hline US Institutional Holdings & $\begin{array}{c}-3.209 * * * \\
{[0.000]}\end{array}$ & $\begin{array}{c}-3.135^{* * * *} \\
{[0.000]}\end{array}$ & $\begin{array}{c}-3.228 * * * \\
{[0.000]}\end{array}$ & $\begin{array}{c}-3.243 * * * \\
{[0.000]}\end{array}$ \\
\hline $\ln$ (Assets) & $\begin{array}{c}-0.110^{* *} \\
{[0.013]}\end{array}$ & $\begin{array}{c}-0.123 * * * \\
{[0.005]}\end{array}$ & $\begin{array}{c}-0.112 * * \\
{[0.011]}\end{array}$ & $\begin{array}{c}-0.090^{* *} \\
{[0.043]}\end{array}$ \\
\hline Debt/Assets & $\begin{array}{c}1.195^{* * *} \\
{[0.004]}\end{array}$ & $\begin{array}{c}1.189 * * * \\
{[0.004]}\end{array}$ & $\begin{array}{c}1.201 * * * \\
{[0.003]}\end{array}$ & $\begin{array}{c}1.132 * * * \\
{[0.005]}\end{array}$ \\
\hline Cash/Assets & $\begin{array}{c}-1.204 * * \\
{[0.017]}\end{array}$ & $\begin{array}{c}-1.345^{* * * *} \\
{[0.007]}\end{array}$ & $\begin{array}{c}-1.185 * * \\
{[0.017]}\end{array}$ & $\begin{array}{c}-1.055^{* * *} \\
{[0.034]}\end{array}$ \\
\hline R\&D/Sales & $\begin{array}{c}0.076 \\
{[0.319]}\end{array}$ & $\begin{array}{c}0.069 \\
{[0.368]}\end{array}$ & $\begin{array}{c}0.084 \\
{[0.273]}\end{array}$ & $\begin{array}{c}0.092 \\
{[0.249]}\end{array}$ \\
\hline Intangibles/Assets & $\begin{array}{c}0.38 \\
{[0.424]}\end{array}$ & $\begin{array}{c}0.325 \\
{[0.490]}\end{array}$ & $\begin{array}{c}0.35 \\
{[0.463]}\end{array}$ & $\begin{array}{c}0.34 \\
{[0.479]}\end{array}$ \\
\hline Advertising/Sales & $\begin{array}{c}1.21 \\
{[0.207]}\end{array}$ & $\begin{array}{c}1.205 \\
{[0.202]}\end{array}$ & $\begin{array}{c}1.238 \\
{[0.186]}\end{array}$ & $\begin{array}{c}1.329 \\
{[0.157]}\end{array}$ \\
\hline I(High Tech) & $\begin{array}{c}0.099 \\
{[0.615]}\end{array}$ & $\begin{array}{c}0.111 \\
{[0.567]}\end{array}$ & $\begin{array}{c}0.126 \\
{[0.515]}\end{array}$ & $\begin{array}{c}0.165 \\
{[0.399]}\end{array}$ \\
\hline FCF/Assets & $\begin{array}{c}0.805^{*} \\
{[0.056]}\end{array}$ & $\begin{array}{l}0.778 * \\
{[0.067]}\end{array}$ & $\begin{array}{c}0.866 * * \\
{[0.039]}\end{array}$ & $\begin{array}{c}0.935 * * \\
{[0.017]}\end{array}$ \\
\hline Trade Imbalance & $\begin{array}{c}0.281 \\
{[0.842]}\end{array}$ & $\begin{array}{l}-1.006 \\
{[0.495]}\end{array}$ & $\begin{array}{c}0.809 \\
{[0.561]}\end{array}$ & $\begin{array}{c}0.328 \\
{[0.824]}\end{array}$ \\
\hline FDI/GDP & $\begin{array}{c}132.678 \\
{[0.242]}\end{array}$ & $\begin{array}{c}127.315 \\
{[0.251]}\end{array}$ & $\begin{array}{l}134.801 \\
{[0.243]}\end{array}$ & $\begin{array}{l}153.893 \\
{[0.183]}\end{array}$ \\
\hline Home Market Cap/GDP & $\begin{array}{c}-28.03 \\
{[0.137]}\end{array}$ & $\begin{array}{l}-28.187 \\
{[0.125]}\end{array}$ & $\begin{array}{c}-32.934 * \\
{[0.099]}\end{array}$ & $\begin{array}{l}-33.523 \\
{[0.104]}\end{array}$ \\
\hline Home Market Turnover & $\begin{array}{l}-0.251^{*} \\
{[0.080]}\end{array}$ & $\begin{array}{c}-0.347^{* *} \\
{[0.019]}\end{array}$ & $\begin{array}{c}-0.207 \\
{[0.157]}\end{array}$ & $\begin{array}{c}-0.145 \\
{[0.347]}\end{array}$ \\
\hline ln(Distance from NY km) & 0.294 & 0.556 & 0.075 & 0.094 \\
\hline
\end{tabular}


abs(Time Zone Difference)

I(Same Language)

Corp Tax Rate

Constant

Observations

Pseudo R-squared

$\mathrm{F}$ test
[0.877]

$-0.665$

[0.266]

2.439

[0.307]

0.917

[0.664]

9.686

[0.487]

3,128

$13.44 \%$

3569
[0.790]

$-0.694$

[0.265]

2.138

[0.396]

2.084

[0.316]

5.113

[0.743]

3,128

$13.67 \%$

4690
[0.972]

$-0.523$

[0.430]

1.09

[0.667]

2.003

[0.352]

8.555

[0.590]

3,128

$13.32 \%$

3722
[0.960]

$-0.597$

[0.320]

2.259

[0.358]

$-0.503$

[0.835]

3.624

[0.793]

3,128

$13.02 \%$

3785 


\section{Figure 1}

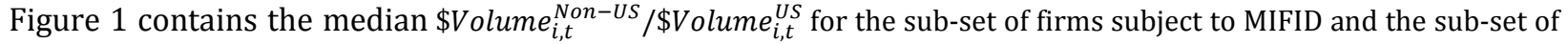
firms that are not subject to MIFID.

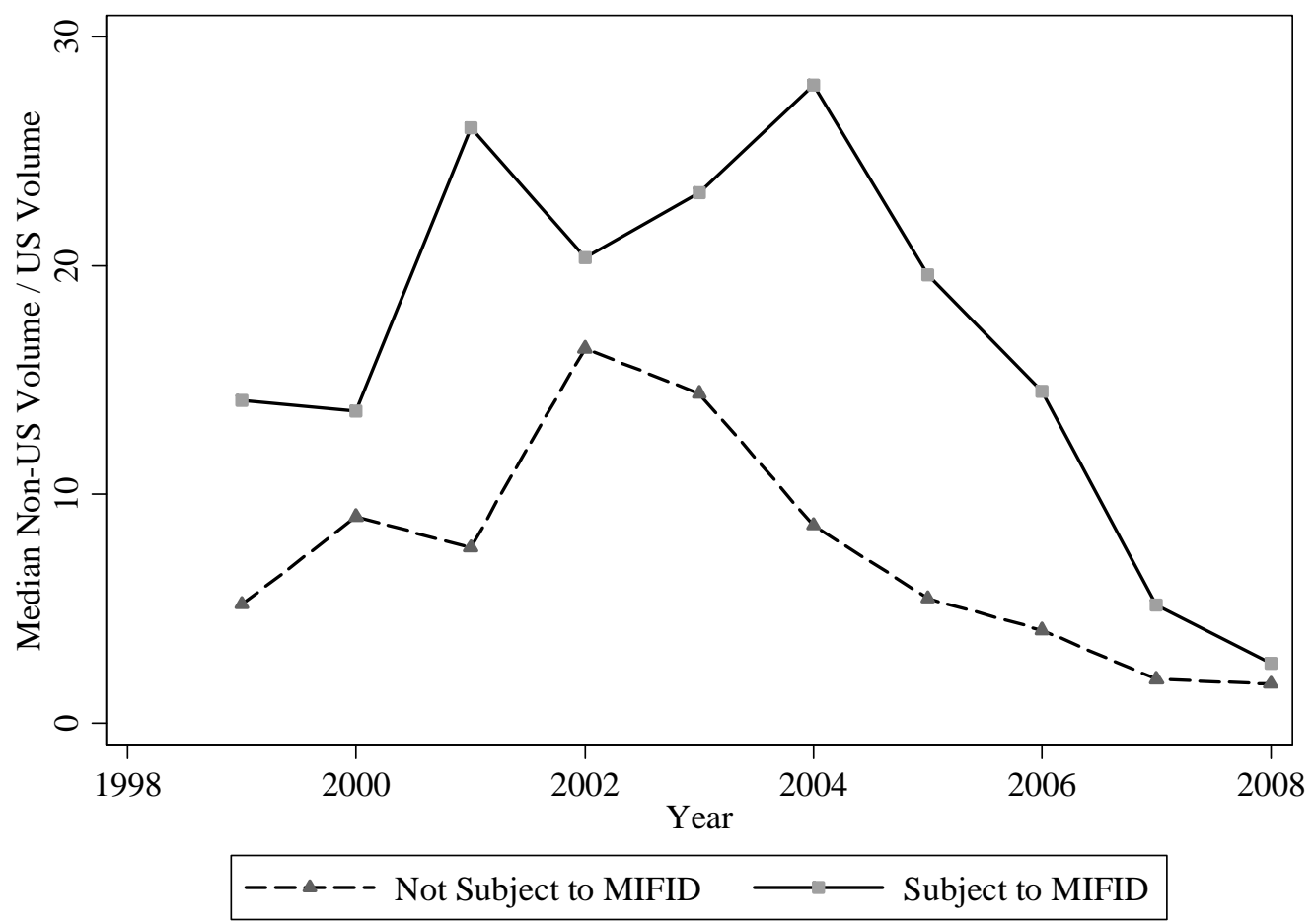


Table 10: MIFID Analysis

This table contains an analysis of the impact of MIFID on the reaction of non-U.S. volume to U.S. volume. 
Table 1 contains the variable definitions. Brackets contain p-values. Superscripts ***, **, and * denote significance at $1 \%$, $5 \%$, and $10 \%$, respectively.

\begin{tabular}{|c|c|c|c|c|c|c|}
\hline \multirow{3}{*}{$\begin{array}{l}\text { Dependent Variable } \\
\text { MIFID Focus } \\
\text { Exchange Dummies }\end{array}$} & \multicolumn{6}{|c|}{$\ln (\$$ Volume Ratio +1) } \\
\hline & \multicolumn{2}{|c|}{$\begin{array}{c}\mathrm{I}(2008)=1 \text { if } 2008 \text { or later; } 0 \\
\text { otherwise }\end{array}$} & \multicolumn{2}{|c|}{$\begin{array}{c}\mathrm{I}(2005)=1 \text { if } 2005 \text { or later; } 0 \\
\text { otherwise }\end{array}$} & \multicolumn{2}{|c|}{$\begin{array}{c}\text { I(Before or After not During 2005) = } 1 \text { if } 2006 \text { or later; } 0 \text { if } 2004 \text { or } \\
\text { earlier }\end{array}$} \\
\hline & NO & YES & NO & YES & NO & YES \\
\hline Column & {$[1]$} & {$[2]$} & {$[3]$} & {$[4]$} & [5] & [6] \\
\hline \multirow{2}{*}{ I(MIFID) } & -0.168 & $\begin{array}{l}-7.06 \\
\end{array}$ & -0.235 & -8.462 & -0.222 & $-9.518^{*}$ \\
\hline & [0.537] & {$[0.211]$} & {$[0.409]$} & {$[0.133]$} & {$[0.435]$} & [0.099] \\
\hline \multirow[t]{2}{*}{$\mathrm{I}(2008)$} & $-0.330 *$ & $-0.563 * * *$ & & & & \\
\hline & {$[0.066]$} & [0.003] & & & & \\
\hline \multirow[t]{2}{*}{ I(2008) * I(MIFID) } & $-0.547 * *$ & $-0.342 *$ & & & & \\
\hline & {$[0.015]$} & [0.099] & & & & \\
\hline \multirow[t]{2}{*}{$\mathrm{I}(2005)$} & & & $-0.313 * *$ & $-0.282 *$ & & \\
\hline & & & {$[0.012]$} & {$[0.050]$} & & \\
\hline \multirow[t]{2}{*}{ I(MIFID) * I(2005) } & & & -0.02 & 0.085 & & \\
\hline & & & {$[0.914]$} & {$[0.638]$} & & \\
\hline \multirow[t]{2}{*}{ I(Before or After not During 2005) } & & & & & $-0.293 * *$ & $-0.288 *$ \\
\hline & & & & & {$[0.026]$} & {$[0.063]$} \\
\hline \multirow{2}{*}{$\begin{array}{l}\text { I*(MIFID) * I(Before or After not During } \\
2005)\end{array}$} & & & & & -0.162 & -0.01 \\
\hline & & & & & [0.419] & {$[0.960]$} \\
\hline \multirow[t]{2}{*}{ Exchange $\ln (\$$ Volume Ratio +1$)$} & $1.027 * * *$ & 0.194 & $1.036 * * *$ & 0.301 & $1.055^{* * *}$ & 0.351 \\
\hline & {$[0.000]$} & [0.395] & {$[0.000]$} & {$[0.182]$} & {$[0.000]$} & {$[0.126]$} \\
\hline \multirow[t]{2}{*}{ US Institutional Holdings } & $-4.535^{* * *}$ & $-3.342^{* * *}$ & $-4.447 * * *$ & $-3.328 * * *$ & $-4.398^{* * *}$ & $-3.349^{* * *}$ \\
\hline & {$[0.000]$} & [0.000] & {$[0.000]$} & [0.000] & {$[0.000]$} & [0.000] \\
\hline \multirow[t]{2}{*}{$\ln$ (Assets) } & -0.002 & $-0.088 * *$ & -0.002 & $-0.084 *$ & -0.018 & $-0.098 * *$ \\
\hline & {$[0.967]$} & {$[0.045]$} & {$[0.960]$} & {$[0.059]$} & {$[0.720]$} & {$[0.031]$} \\
\hline \multirow[t]{2}{*}{ Debt/Assets } & $1.519 * * *$ & $1.113^{* * *}$ & $1.528 * * *$ & $1.147^{* * *}$ & $1.584^{* * *}$ & $1.191^{* * *}$ \\
\hline & {$[0.001]$} & {$[0.006]$} & {$[0.001]$} & {$[0.005]$} & {$[0.000]$} & {$[0.004]$} \\
\hline \multirow[t]{2}{*}{ Cash/Assets } & $-1.025^{*}$ & $-1.061^{* *}$ & $-0.986^{*}$ & $-1.029 * *$ & $-1.163^{* *}$ & $-1.212^{* *}$ \\
\hline & {$[0.054]$} & [0.036] & {$[0.060]$} & {$[0.040]$} & [0.030] & [0.018] \\
\hline \multirow[t]{2}{*}{ R\&D/Sales } & 0.087 & 0.108 & 0.101 & 0.119 & 0.122 & $0.138^{*}$ \\
\hline & {$[0.281]$} & {$[0.160]$} & {$[0.207]$} & {$[0.118]$} & [0.139] & {$[0.082]$} \\
\hline
\end{tabular}




\begin{tabular}{|c|c|c|c|c|c|c|}
\hline Intangibles/Assets & $\begin{array}{c}0.475 \\
{[0.357]}\end{array}$ & $\begin{array}{c}0.46 \\
{[0.334]}\end{array}$ & $\begin{array}{c}0.519 \\
{[0.316]}\end{array}$ & $\begin{array}{c}0.485 \\
{[0.310]}\end{array}$ & $\begin{array}{c}0.504 \\
{[0.326]}\end{array}$ & $\begin{array}{c}0.5 \\
{[0.291]}\end{array}$ \\
\hline \multirow[t]{2}{*}{ Advertising/Sales } & $2.313^{* *}$ & 1.363 & $2.215^{* *}$ & 1.332 & $2.247^{* *}$ & 1.421 \\
\hline & {$[0.030]$} & {$[0.148]$} & {$[0.036]$} & {$[0.157]$} & {$[0.028]$} & {$[0.120]$} \\
\hline \multirow[t]{2}{*}{ I(High Tech) } & -0.022 & 0.151 & -0.025 & 0.143 & -0.065 & 0.093 \\
\hline & [0.915] & {$[0.438]$} & {$[0.904]$} & {$[0.466]$} & {$[0.756]$} & {$[0.641]$} \\
\hline \multirow[t]{2}{*}{ FCF/Assets } & $0.991^{* *}$ & $1.029 * *$ & $1.038^{* *}$ & $1.090^{* * *}$ & $1.134^{* *}$ & $1.197 * * *$ \\
\hline & {$[0.030]$} & {$[0.011]$} & {$[0.026]$} & [0.008] & {$[0.014]$} & {$[0.004]$} \\
\hline \multirow[t]{2}{*}{ Trade Imbalance } & -1.062 & 0.11 & -1.167 & -0.294 & -1.273 & -0.27 \\
\hline & {$[0.405]$} & [0.941] & [0.355] & [0.839] & {$[0.310]$} & [0.852] \\
\hline \multirow[t]{2}{*}{ FDI/GDP } & -86.214 & 13.794 & -92.154 & 9.888 & -156.099 & -29.528 \\
\hline & [0.477] & [0.903] & {$[0.447]$} & {$[0.930]$} & {$[0.237]$} & {$[0.812]$} \\
\hline \multirow[t]{2}{*}{ Home Market Cap/GDP } & -23.321 & $-46.163 * *$ & -16.724 & $-30.609 *$ & -14.685 & $-28.772 *$ \\
\hline & {$[0.114]$} & {$[0.014]$} & {$[0.228]$} & {$[0.078]$} & {$[0.282]$} & {$[0.086]$} \\
\hline \multirow[t]{2}{*}{ Home Market Turnover } & -0.069 & -0.104 & -0.04 & -0.094 & -0.001 & -0.06 \\
\hline & {$[0.644]$} & {$[0.452]$} & {$[0.801]$} & {$[0.520]$} & [0.993] & {$[0.684]$} \\
\hline \multirow[t]{2}{*}{ ln(Distance from NY km) } & $-1.559 * * *$ & 0.229 & $-1.522 * * *$ & 0.456 & $-1.490 * * *$ & 0.94 \\
\hline & [0.001] & [0.902] & [0.001] & {$[0.808]$} & {$[0.001]$} & {$[0.636]$} \\
\hline \multirow[t]{2}{*}{ abs(Time Zone Difference) } & $0.189 * * *$ & -0.531 & $0.184^{* * *}$ & -0.673 & $0.188 * * *$ & -0.791 \\
\hline & {$[0.000]$} & {$[0.374]$} & {$[0.000]$} & {$[0.266]$} & {$[0.000]$} & {$[0.205]$} \\
\hline \multirow[t]{2}{*}{ I(Same Language) } & 0.429 & -4.734 & 0.397 & -5.408 & 0.397 & -6.104 \\
\hline & {$[0.107]$} & {$[0.174]$} & [0.139] & [0.132] & {$[0.136]$} & {$[0.103]$} \\
\hline \multirow[t]{2}{*}{ Corp Tax Rate } & -1.823 & -1.797 & -1.581 & -1.053 & -1.691 & -1.35 \\
\hline & [0.296] & {$[0.440]$} & {$[0.355]$} & {$[0.656]$} & {$[0.321]$} & {$[0.570]$} \\
\hline \multirow[t]{2}{*}{ Constant } & $15.641^{* * *}$ & 13.325 & $15.279 * * *$ & 13.089 & $15.104^{* * *}$ & 10.819 \\
\hline & {$[0.000]$} & [0.269] & {$[0.000]$} & {$[0.242]$} & {$[0.000]$} & {$[0.358]$} \\
\hline Observations & 3,128 & 3,128 & 3,128 & 3,128 & 2,805 & 2,805 \\
\hline Pseudo R-squared & $7.42 \%$ & $12.70 \%$ & $7.40 \%$ & $12.57 \%$ & $7.73 \%$ & $12.69 \%$ \\
\hline F test & 24 & 4198 & 20 & 4493 & 21 & 3013 \\
\hline
\end{tabular}


Table 11: Controlling for the information share

This table focuses on the controlling for the 'information share' of the US market. Section 4.3 describes the computation of the information share in detail. The models are Tobit models (with a lower bound of zero) that include year and exchange dummies and cluster standard errors by firm. 
Table 1 contains the variable definitions. Brackets contain p-values. Superscripts ${ }^{* * *}, * *$, and ${ }^{*}$ denote significance at $1 \%, 5 \%$, and $10 \%$, respectively.

\begin{tabular}{|c|c|c|c|c|}
\hline \multirow{3}{*}{$\begin{array}{l}\text { Dependent Variable } \\
\text { Model } \\
\text { Column }\end{array}$} & \multicolumn{4}{|c|}{$\ln (\$$ Volume Ratio +1) } \\
\hline & \multicolumn{4}{|c|}{ Tobit, Year Dummies, Exchange Dummies, Firm Clustering } \\
\hline & {$[1]$} & [2] & [3] & [4] \\
\hline WB Governance Index & $\begin{array}{l}2.256^{*} \\
{[0.075]}\end{array}$ & & & \\
\hline S\&P Rating & & $\begin{array}{c}0.131^{* * *} \\
{[0.003]}\end{array}$ & & \\
\hline ICRG Composite Index & & & $\begin{array}{c}4.775 * * \\
{[0.016]}\end{array}$ & \\
\hline ADRI (Spamann) & & & & $\begin{array}{c}-0.061 \\
{[0.762]}\end{array}$ \\
\hline Rules Index & $\begin{array}{c}4.462^{* * *} \\
{[0.000]}\end{array}$ & $\begin{array}{c}4.157 * * * \\
{[0.000]}\end{array}$ & $\begin{array}{c}4.194 * * * \\
{[0.000]}\end{array}$ & $\begin{array}{c}4.625 * * * \\
{[0.000]}\end{array}$ \\
\hline Squared Rules Index & $\begin{array}{c}-1.310 * * * \\
{[0.000]}\end{array}$ & $\begin{array}{c}-1.177^{* * *} \\
{[0.000]}\end{array}$ & $\begin{array}{c}-1.210 * * * \\
{[0.000]}\end{array}$ & $\begin{array}{c}-1.389 * * * \\
{[0.000]}\end{array}$ \\
\hline Information Share & $\begin{array}{c}0.020 \\
{[0.179]}\end{array}$ & $\begin{array}{c}0.017 \\
{[0.245]}\end{array}$ & $\begin{array}{c}0.019 \\
{[0.202]}\end{array}$ & $\begin{array}{c}0.020 \\
{[0.176]}\end{array}$ \\
\hline Exchange $\ln (\$$ Volume Ratio +1) & $\begin{array}{c}0.072 \\
{[0.752]}\end{array}$ & $\begin{array}{c}0.063 \\
{[0.784]}\end{array}$ & $\begin{array}{c}0.064 \\
{[0.781]}\end{array}$ & $\begin{array}{c}0.088 \\
{[0.701]}\end{array}$ \\
\hline US Institutional Holdings & $\begin{array}{c}-3.195 * * * \\
{[0.000]}\end{array}$ & $\begin{array}{c}-3.135 * * * \\
{[0.000]}\end{array}$ & $\begin{array}{c}-3.186 * * * \\
{[0.000]}\end{array}$ & $\begin{array}{c}-3.245^{* * *} \\
{[0.000]}\end{array}$ \\
\hline $\ln$ (Assets) & $\begin{array}{c}-0.107^{* *} \\
{[0.015]}\end{array}$ & $\begin{array}{c}-0.120 * * * \\
{[0.007]}\end{array}$ & $\begin{array}{c}-0.109 * * \\
{[0.013]}\end{array}$ & $\begin{array}{c}-0.095 * * \\
{[0.032]}\end{array}$ \\
\hline Debt/Assets & $\begin{array}{c}1.145^{* * *} \\
{[0.005]}\end{array}$ & $\begin{array}{c}1.127 * * * \\
{[0.005]}\end{array}$ & $\begin{array}{c}1.157 * * * \\
{[0.004]}\end{array}$ & $\begin{array}{c}1.156 * * * \\
{[0.004]}\end{array}$ \\
\hline Cash/Assets & $\begin{array}{c}-1.118 * * \\
{[0.024]}\end{array}$ & $\begin{array}{c}-1.283^{* * *} \\
{[0.010]}\end{array}$ & $\begin{array}{c}-1.153^{* *} \\
{[0.020]}\end{array}$ & $\begin{array}{c}-1.032 * * \\
{[0.037]}\end{array}$ \\
\hline R\&D/Sales & $\begin{array}{c}0.075 \\
{[0.334]}\end{array}$ & $\begin{array}{c}0.066 \\
{[0.401]}\end{array}$ & $\begin{array}{c}0.081 \\
{[0.299]}\end{array}$ & $\begin{array}{c}0.088 \\
{[0.264]}\end{array}$ \\
\hline Intangibles/Assets & $\begin{array}{c}0.382 \\
{[0.420]}\end{array}$ & $\begin{array}{c}0.289 \\
{[0.539]}\end{array}$ & $\begin{array}{c}0.366 \\
{[0.441]}\end{array}$ & $\begin{array}{c}0.371 \\
{[0.436]}\end{array}$ \\
\hline Advertising/Sales & $\begin{array}{c}1.186 \\
{[0.198]}\end{array}$ & $\begin{array}{c}1.164 \\
{[0.208]}\end{array}$ & $\begin{array}{c}1.147 \\
{[0.216]}\end{array}$ & $\begin{array}{c}1.235 \\
{[0.179]}\end{array}$ \\
\hline I(High Tech) & $\begin{array}{c}0.147 \\
{[0.441]}\end{array}$ & $\begin{array}{c}0.165 \\
{[0.381]}\end{array}$ & $\begin{array}{c}0.161 \\
{[0.393]}\end{array}$ & $\begin{array}{c}0.164 \\
{[0.381]}\end{array}$ \\
\hline FCF/Assets & $\begin{array}{c}0.841 * * \\
{[0.033]}\end{array}$ & $\begin{array}{c}0.818 * * \\
{[0.040]}\end{array}$ & $\begin{array}{c}0.860 * * \\
{[0.031]}\end{array}$ & $\begin{array}{c}0.878 * * \\
{[0.024]}\end{array}$ \\
\hline Trade Imbalance & $\begin{array}{c}0.654 \\
{[0.653]}\end{array}$ & $\begin{array}{c}-0.368 \\
{[0.806]}\end{array}$ & $\begin{array}{c}1.426 \\
{[0.318]}\end{array}$ & $\begin{array}{c}0.539 \\
{[0.714]}\end{array}$ \\
\hline FDI/GDP & $\begin{array}{c}118.637 \\
{[0.277]}\end{array}$ & $\begin{array}{c}137.968 \\
{[0.205]}\end{array}$ & $\begin{array}{c}117.558 \\
{[0.291]}\end{array}$ & $\begin{array}{c}126.956 \\
{[0.264]}\end{array}$ \\
\hline
\end{tabular}




\begin{tabular}{|c|c|c|c|c|}
\hline Home Market Cap/GDP & $\begin{array}{c}-30.834 \\
{[0.135]}\end{array}$ & $\begin{array}{c}-27.325 \\
{[0.169]}\end{array}$ & $\begin{array}{c}-33.01 \\
{[0.112]}\end{array}$ & $\begin{array}{l}-27.424 \\
{[0.179]}\end{array}$ \\
\hline Home Market Turnover & $\begin{array}{c}-0.354 * * \\
{[0.013]}\end{array}$ & $\begin{array}{c}-0.386 * * * \\
{[0.006]}\end{array}$ & $\begin{array}{c}-0.268 * \\
{[0.056]}\end{array}$ & $\begin{array}{c}-0.189 \\
{[0.208]}\end{array}$ \\
\hline $\ln$ (Distance from NY km) & $\begin{array}{c}1.222 \\
{[0.629]}\end{array}$ & $\begin{array}{c}1.284 \\
{[0.618]}\end{array}$ & $\begin{array}{c}0.991 \\
{[0.708]}\end{array}$ & $\begin{array}{c}1.048 \\
{[0.681]}\end{array}$ \\
\hline abs(Time Zone Difference) & $\begin{array}{c}-0.623 \\
{[0.388]}\end{array}$ & $\begin{array}{c}-0.676 \\
{[0.345]}\end{array}$ & $\begin{array}{c}-0.519 \\
{[0.477]}\end{array}$ & $\begin{array}{c}-0.548 \\
{[0.455]}\end{array}$ \\
\hline I(Same Language) & $\begin{array}{c}2.786 \\
{[0.405]}\end{array}$ & $\begin{array}{c}2.759 \\
{[0.405]}\end{array}$ & $\begin{array}{c}1.944 \\
{[0.553]}\end{array}$ & $\begin{array}{c}2.511 \\
{[0.462]}\end{array}$ \\
\hline Corp Tax Rate & $\begin{array}{c}1.754 \\
{[0.418]}\end{array}$ & $\begin{array}{c}2.061 \\
{[0.351]}\end{array}$ & $\begin{array}{c}1.557 \\
{[0.482]}\end{array}$ & $\begin{array}{c}0.43 \\
{[0.862]}\end{array}$ \\
\hline Constant & $\begin{array}{c}-8.945 \\
{[0.646]}\end{array}$ & $\begin{array}{c}-9.707 \\
{[0.624]}\end{array}$ & $\begin{array}{c}-9.321 \\
{[0.646]}\end{array}$ & $\begin{array}{c}-5.669 \\
{[0.771]}\end{array}$ \\
\hline Observations & 3,081 & 3,081 & 3,081 & 3,081 \\
\hline Pseudo R-squared & $13.20 \%$ & $13.42 \%$ & $13.26 \%$ & $13.09 \%$ \\
\hline F-Statistic & 41.5063 & 41.2771 & 36.3531 & 39.94 \\
\hline
\end{tabular}




\section{References}

Aitken, M., Siow, A., 2003. Ranking equity markets on the basis of market efficiency and integrity, in: Skeete, H. (Ed.), Hewlett-Packard Handbook of World Stock, Derivative \& Commodity Exchanges. Mondo Visone, Dublin, p. xliv-lv.

Aitken, M.J., Harris, F.H. deB, Sensenbrenner, F.J., 2011. Price Discovery in Liquid British Shares Pre and Post MiFID: The Role of MTFs (Working Paper).

Apodaca, C., 2004. The rule of law and human rights. Juridacature 87, 292-299.

Bailey, W., Chung, Y.P., 1995. Exchange Rate Fluctuations, Political Risk, and Stock Returns: Some Evidence from an Emerging Market. Journal of Financial and Quantitative Analysis 30, 541-561.

Baruch, S., Karolyi, G.A., Lemmon, M.L., 2007. Multimarket Trading and Liquidity: Theory and Evidence. Journal of Finance 62, 2169-2200.

Beny, L.N., 2005. Do insider trading laws matter? Some preliminary comparative evidence. American Law and Economics Review 7, 144-183.

Bhattacharya, U., Daouk, H., 2009. When no law is better than a good law. Review of Finance 13, 577-627.

Boot, A.W.A., Gopalan, R., Thakor, A.V., 2006. The entrepreneur's choice between private and public ownership. Journal of Finance 61, 803-836.

Borensztein, E., De Gregorio, J., Lee, J.-W., 1998. How does foreign direct investment affect economic growth? Journal of International Economics 45, 115-135.

Boubakri, N., Cosset, J.-C., Saffar, W., 2008. Political connections of newly privatized firms. Journal of Corporate Finance 14.

Braun, M., Di Tella, R., 2004. Inflation, Inflation Variability, and Corruption. Economics \& Politics 16, 77-100.

Brockman, P., Chung, D.Y., 2003. Investor Protection and Firm Liquidity. Journal of Finance 58, 921-938.

Bruno, V., Claessens, S., 2010. Corporate governance and regulation: Can there be too much of a good thing? Journal of Financial Intermediation 19, 461-482.

Burkart, M., Gromb, D., Panunzi, F., 1997. Large shareholders, monitoring, and the value of the firm. Quarterly Journal of Economics 112, 693-728.

Chen, H., Choi, P.M.S., Kim, H., 2008. American depositary receipts: Asia-Pacific evidence on convergence and dynamics. Journal of Multinational Financial Management 18, 346-368.

Coffee, J.C., 2005. Causation By Presumption? Why the Supreme Court Should Reject Phantom Losses and Reverse Broudo. Business Lawyer 60, 533-549.

Coffee, J.C., 2006. Reforming the Securities Class Action: An Essay on Deterrence and Its Implementation. Columbia Law Review 106, 1534-1586.

Comerton-Forde, C., Rydge, J., 2006. Market integrity and surveillance effort. Journal of Financial Services Research 29, 149-172.

Committee of Wise Men, 2001. Final Report of The Committee of Wise Men on The Regulation of European Securities Markets. European Commission.

Craswell, R., Calfee, J.E., 1986. Deterrence and Uncertain Legal Standards. Journal of Law, Economics \& Organization 2, 279-303.

Cumming, D., Johan, S., 2008. Global market surveillance. American Law and Economics Review 10, 454-506.

Cumming, D., Johan, S., Li, D., 2011. Exchange trading rules and stock market liquidity. Journal of Financial Economics 99, 651-671.

Daske, H., Hail, L., Leuz, C., Verdi, R., 2008. Mandatory IFRS reporting around the world: Early evidence on the economic consequences. Journal of Accounting Research 46, 1085-1142.

Desyllas, P., Hughes, A., 2010. Do high technology acquirers become more innovative? Research Policy 39, 1105-1121.

Doidge, C., Karolyi, G.A., Lins, K., Stulz, R., 2009a. Private benefits of control, ownership, and the cross-listing decision. Journal of Finance 64, 425-466.

Doidge, C., Karolyi, G.A., Stulz, R., 2009b. Has New York become less competitive than London in global markets? Evaluating foreign listing choices over time. Journal of Financial Economics 91, 253-277. 
Doidge, C., Karolyi, G.A., Stulz, R.M., 2004. Why are foreign firms listed in the U.S. worth more? Journal of Financial Economics 71, 205-238.

Dollar, D., Kraay, A., 2003. Institutions, trade and growth. Journal of Monetary Economics 50, 133-162.

Durnev, A.A., Nain, A.S., 2007. Does insider trading regulation deter private information trading? International evidence. Pacific-Basin Finance Journal 15, 409-433.

Erb, C.B., Harvey, C.R., Viskanta, T.E., 1996. Political Risk, Economic Risk, and Financial Risk. Financial Analysts Journal 52, 29-46.

Foerster, S.R., Karolyi, G.A., 2000. The Long-Run Performance of Global Equity Offerings. Journal of Financial and Quantitative Analysis 35, 499-528.

Fong, K., Holden, C.W., Trzcinka, C.A., 2011. What Are The Best Liquidity Proxies For Global Research? (Working Paper).

Fox, M.B., 2005. Demystifying Causation in Fraud-on-the-Market Actions. Business Lawyer 60, 507-532.

Fox, M.B., 2006. After Dura: Causation in Fraud-on-the-Market Actions. Journal of Corporation Law 31, 829876.

Gagnon, L., Karolyi, G.A., 2009. Information, Trading Volume, and International Stock Return Comovements: Evidence from Cross-Listed Stocks. Journal of Financial and Quantitative Analysis 44, 953-986.

Gagnon, L., Karolyi, G.A., 2010. Multi-market trading and arbitrage. Journal of Financial Economics 97, 53-80.

Giovannini, A., Jorion, P., 1987. Interest rates and risk premia in the stock market and in the foreign exchange market. Journal of International Money and Finance 6, 107-123.

Giraud, J.R., 2009. MiFID: One Year On (Position Paper), Position Paper. EDHEC Risk and Asset Management Research Centre.

Gradstein, M., 2007. Inequality, democracy and the protection of property rights. Economic Journal 117, 252269.

Graham, R., 2002. A Unified Theory of Statutory Interpretation. Statute Law Review 23, 91-134.

Grinblatt, M., Keloharju, M., 1999. The Investment Behavior and Performance of Various Investor Types: A Study of Finland's Unique Data Set. Journal of Financial Economics 55, 43-67.

Grullon, G., Kanatas, G., Weston, J.P., 2004. Advertising, Breadth of Ownership, and Liquidity. Review of Financial Studies 17, 439-461.

Gu, F., Wang, W., 2005. Intangible Assets, Information Complexity, and Analysts' Earnings Forecasts. Journal of Business Finance \& Accounting 32, 1673-1702.

Hail, L., Leuz, C., 2009. Cost of Capital Effects and Changes in Growth Expectations around U.S. Cross Listings. Journal of Financial Economics 93, 428-454.

Hail, L., Luez, C., 2006. International differences in the cost of equity capital: do legal institutions and securities regulation matter? Journal of Accounting Research 44, 485-531.

Halling, M., Pagano, M., Randl, O., Zechner, J., 2008. Where is the Market? Evidence from Cross-Listings in the U.S. Review of Financial Studies 21, 725-761.

Hamada, K., 1966. Strategic Aspects of Taxation on Foreign Investment Income. Quarterly Journal of Economics 80, 361-375.

Harford, J., Klasa, S., Walcott, N., 2009. Do firms have leverage targets? Evidence from acquisitions. Journal of Financial Economics 93, 1-14.

Harris, F.H. deB, McInish, T.H., Wood, R.A., 2011. The Need for A Unified Approach to Price Discovery: CFS and IS Metrics Before and After Reg NMS (Working Paper).

Hau, H., 2001. Location Matters: An Examination of Trading Profits. Journal of Finance 56, 1959-1983.

Humphery-Jenner, M.L., 2009. Should Common Law Doctrines Dynamically Guide the Interpretation of Statutes? Legisprudence 3, 171-189.

Humphery-Jenner, M.L., 2011. Securities Fraud Compensation: A legislative scheme drawing on China, the US and the UK. Legal Issues of Economic Integration 38, 143-162.

Jackson, H.E., Roe, M.J., 2009. Public and private enforcement of securities laws: Resource-based evidence. Journal of Financial Economics 93, 207-238.

Janeba, E., 1995. Corporate income tax competition, double taxation treaties, and foreign direct investment. Journal of Public Economics 56, 311-325.

Jensen, M.C., 1986. Agency costs of free cash flow, corporate finance, and takeovers. American Economic Review 76, 323-329.

Kaminsky, G., Schmukler, S., 2002. Emerging Market Instability: Do Sovereign Ratings Affect Country Risk and Stock Returns? World Bank Economic Review 16, 171-195. 
Kayhan, A., Titman, S., 2007. Firms' histories and their capital structures. Journal of Financial Economics 83, $1-32$.

Kleinknecht, A., Van Montfort, K., Brouwer, E., 2002. The non-trivial choice between innovation indicators. Economics of Innovation \& New Technology 11, 109-121.

Lambert, R., Leuz, C., Verrecchia, R.E., 2007. Accounting information, disclosure, and the cost of capital. Journal of Accounting Research 45, 385-420.

Loughran, T., Ritter, J., 2004. Why Has IPO Underpricing Changed Over Time? Financial Management 33, 5-37.

Maloney, M.T., McCormick, R.E., Mitchell, M.L., 1993. Managerial decision making and capital structure. Journal of Business 66, 189-217.

McCahery, J., Sautner, Z., Starks, L., 2010. Behind the Scenes: The Corporate Governance Preferences of Institutional Investors (Working Paper No. 010-2010), Working Paper. Tilburg University.

Merrick, J.J., Naik, N.Y., Yadav, P.K., 2005. Strategic trading behavior and price distortion in a manipulated market: Anatomy of a squeeze. Journal of Financial Economics 77, 171-218.

Miller, D.P., 1999. The market reaction to international cross-listings: evidence from depositary receipts. Journal of Financial Economics 51, 103-123.

MSCI, 2011. MSCI Global Market AccessibilityReview (MSCI Index Research). MSCI.

Neumayer, E., 2002. Do democracies exhibit stronger international environmental commitment? A crosscountry analysis. Journal of Peace Research 39, 139-164.

Petrella, G., 2010. MiFID, Reg NMS and competition across trading venues in Europe and the USA. Journal of Financial Regulation and Compliance 18, 257-271.

La Porta, R., Lopez-de-Silanes, F., Shleifer, A., 2006. What Works in Securities Laws? Journal of Finance 61, 132.

La Porta, R., Lopez-de-Silanes, F., Shleifer, A., 2008. The Economic Consequences of Legal Origins. Journal of Economic Literature 46, 285-332.

La Porta, R., Lopez-de-Silanes, F., Shleifer, A., Vishny, R.W., 1997. Legal Determinants of External Finance. Journal of Finance 52, 1131-1150.

La Porta, R., Lopez-de-Silanes, F., Shleifer, A., Vishny, R.W., 1998. Law and finance. Journal of Political Economy 106, 1113-1155.

Prodi, R., 2002. Implementation of financial services legislation in the context of the Lamfalussy Report.

Ragozzino, R., Reuer, J.J., 2011. Geographic distance and corporate acquisitions: signals from IPO fi_rms. Strategic Management Journal Forthcoming.

Reese, W.A., Weisbach, M.S., 2002. Protection of minority shareholder interests, cross-listings in the United States, and subsequent equity offerings. Journal of Financial Economics 66, 65-104.

Sarkissian, S., Schill, M.J., 2004. The Overseas Listing Decision: New Evidence of Proximity Preference. Review of Financial Studies 17, 769-809.

Spamann, H., 2010. The “Antidirector Rights Index" Revisited. Review of Financial Studies 23, 467-486.

Thomas, M.A., 2010. What Do the Worldwide Governance Indicators Measure? European Journal of Development Research 22, 31-54.

Wagner, H., 2005. Economic Analysis of Cross-Border Legal Uncertainty: The Example of the European Union, in: Smits, J. (Ed.), The Need for a European Contract Law. Empirical and Legal Perspectives. Europa Law Publishing, Groningen, pp. 25-51.

Wagner, H., 2007. Costs of Legal Uncertainty: Is Harmonization a Solution, in: UNCITRAL Congress "Modern Law for Global Commerce". Presented at the UNCITRAL Congress "Modern Law for Global Commerce." 
Home Search Browse Submit Subscribe Shopping Cart My Briefcase Top Papers Top Authors Top Institutions SSRN Blog

Search Within Results $\theta$

Feedback to SSRN (Beta)

SSRN eLibrary Statistics:

Papers \& Authors:

Abstracts:

Full Text Papers:

427,451

Authors:

346,185

197,488

Papers Received in

Last 12 months:

66,593

Paper Downloads:

To date:

$55,406,839$

Last 12 months: $9,592,673$

Last 30 days: $\quad 824,611$

CiteReader: What's this?

Papers with

Resolved

References:

Total References: $\quad 7,658,025$

Papers with Cites: 218,550

Total Citation $\quad 5,212,103$

Links

Papers with

Resolved

Footnotes:

70,041
894,576

$\square$ eDocument is available from

the SSRN eLibrary for free

[\$] eDocument is available, fee

may apply

\section{SSRN e Library Search Results}

24th Australasian Finance \& Banking Conference 2011

9,124 total downloads | Link to this page | Subscribe to this eJournal (requires login)

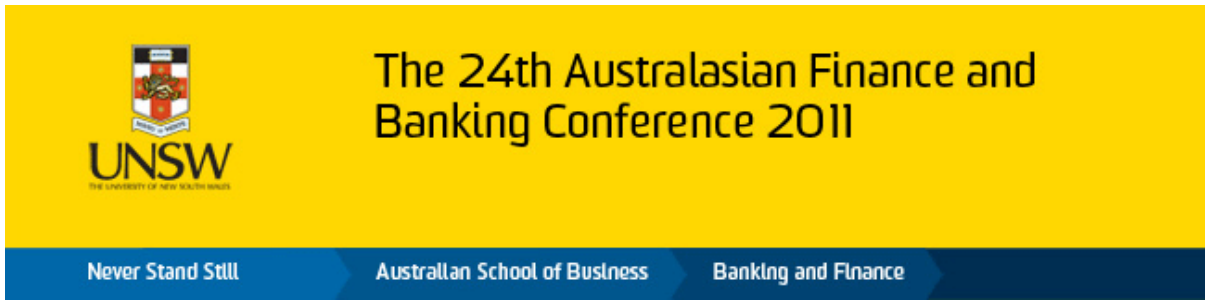

ISBN Number: 978-0-9873127-3-0

Showing Papers $101-121$ of 121

Sort By Date Posted, Descending

<Previous | $1 \underline{2} 3$

$\square$ Liquidity Considerations in Estimating Implied Volatility

24th Australasian Finance and Banking Conference 2011 Paper

Rohini Grover and Susan Thomas

Indira Gandhi Institute of Development Research (IGIDR) and Indira Gandhi Institute of Development Research (IGIDR)

Date Posted: May 11, 2011

Last Revised: November 14, 2011

Working Paper Series

53 downloads

Against the Tide: The Commencement of Short Selling and Margin Trading in Mainland China

24th Australasian Finance and Banking Conference 2011 Paper

Saqib Sharif, Hamish D. Anderson and Ben R. Marshall

Massey University - School of Economics and Finance, Massey University - School of Economics and Finance and Massey University -

Department of Economics and Finance

Date Posted: April 27, 2011

Last Revised: October 06, 2011

Working Paper Series

97 downloads

$\square$ Forced Board Changes: Evidence from Norway

NHH Dept. of Economics Discussion Paper No. 5/2011, 24th Australasian Finance and Banking Conference 2011 Paper Knut Nygaard

Norwegian School of Economics (NHH)

Date Posted: March 25, 2011

Last Revised: January 31, 2012

Working Paper Series

130 downloads

$\square$ Exchange Trading Rules, Governance, and Trading Location of Cross-Listed Stocks

24th Australasian Finance and Banking Conference 2011 Paper, 2012 Financial Markets \& Corporate Governance Conference

Douglas Cumming, Mark Humphery-Jenner and Eliza Wu

York University - Schulich School of Business, University of New South Wales (UNSW) - School of Banking and Finance and University of Technology, Sydney - UTS Business School

Date Posted: March 23, 2011

Last Revised: December 25, 2011

Working Paper Series

63 downloads

$\square$ Do Wealth Creating Mergers and Acquisitions Really Hurt Acquirer Shareholders?

AFA 2012 Chicago Meetings Paper, 24th Australasian Finance and Banking Conference 2011 Paper

Ronald W. Masulis, Peter L. Swan and Brett Tobiansky

Australian School of Business at UNSW, University of New South Wales (UNSW) and University of New South Wales

Date Posted: March 22, 2011

Last Revised: June 11, 2012

Working Paper Series

104 downloads

Capital Regulation and Tail Risk

24th Australasian Finance and Banking Conference 2011 Paper

Enrico C. Perotti, Lev Ratnovski and Razvan Vlahu

University of Amsterdam - Finance Group , International Monetary Fund and De Nederlandsche Bank

Date Posted: March 18, 2011

Last Revised: October 06, 2011

Working Paper Series

91 downloads

$\square$ Closing Call Auctions at the Index Futures Market

24th Australasian Finance and Banking Conference 2011 Paper

Björn Hagströmer and Lars L. Norden

Stockholm University - School of Business and Stockholm University - School of Business 
Date Posted: March 17, 2011

Last Revised: August 22, 2011

Working Paper Series

79 downloads

The Impact of the Originate-to-Distribute Model on Banks Before and During the Financial Crisis

24th Australasian Finance and Banking Conference 2011 Paper

Richard J. Rosen

Federal Reserve Bank of Chicago - Economic Research

Date Posted: March 15, 2011

Last Revised: August 26, 2011

Working Paper Series

43 downloads

$\square$ Who Directs the Fed?

24th Australasian Finance and Banking Conference 2011 Paper

Renee B. Adams

University of New South Wales

Date Posted: March 15, 2011

Last Revised: August 19, 2011

Working Paper Series

52 downloads

A Jump Diffusion Model for Spot Electricity Prices and Market Price of Risk

24th Australasian Finance and Banking Conference 2011 Paper

Ramaprasad Bhar, David B. Colwell and Yuewen Xiao

University of New South Wales (UNSW) - School of Banking and Finance, University of New South Wales (UNSW) - School of Banking and Finance and University of New South Wales (UNSW) - School of Banking and Finance

Date Posted: March 01, 2011

Last Revised: August 23, 2011

Working Paper Series

88 downloads

Which Firms Benefit from Bribes, and By How Much? Evidence from Corruption Cases Worldwide

24th Australasian Finance and Banking Conference 2011 Paper

Stephen Yan-Leung Cheung, Raghavendra Rau and Aris Stouraitis

City University of Hong Kong (CityUHK) - Department of Economics \& Finance, University of Cambridge and Hong Kong Baptist

University (HKBU) - Department of Finance and Decision Sciences

Date Posted: February 28, 2011

Last Revised: January 14, 2012

Working Paper Series

421 downloads

Pitfalls in Modeling Loss Given Default of Bank Loans

24th Australasian Finance and Banking Conference 2011, Midwest Finance Association 2012 Annual Meetings Paper

Martin Hibbeln and Marc Gürtler

University of Braunschweig - Institute of Technology, Department of Finance and University of Braunschweig - Institute of Technology,

Department of Finance

Date Posted: February 10, 2011

Last Revised: September 09, 2011

Working Paper Series

163 downloads

The Lure of the Slant: Analyst Optimism and Asset Prices

AFA 2012 Chicago Meetings Paper, 24th Australasian Finance and Banking Conference 2011 Paper

Craig Brown

National University of Singapore (NUS) - Department of Finance

Date Posted: January 24, 2011

Last Revised: March 28, 2012

Working Paper Series

141 downloads

$\square$ Corporate Pension Funding Status and the Market for Corporate Control: The Disciplinary Role of Pension Deficits in Mergers and Acquisitions

24th Australasian Finance and Banking Conference 2011 Paper

Xn Chang, Jun-Koo Kang and Wenrui Zhang

Nanyang Technological University (NTU) - Nanyang Business School, Nanyang Technological University (NTU) - Nanyang Business School and Nanyang Technological University (NTU) - Nanyang Business School

Date Posted: January 07, 2011

Last Revised: May 18, 2012

Working Paper Series

109 downloads

$\square$ Options Trading and the Extent that Stock Prices Lead Future Earnings Information

Finance and Corporate Governance Conference, 2011, 24th Australasian Finance and Banking Conference 2011 Paper

Cameron Truong

Monash University

Date Posted: December 01, 2010

Last Revised: August 02, 2011

Accepted Paper Series

67 downloads

Public Information and IPO Underpricing

24th Australasian Finance and Banking Conference 2011 Paper, ECGI - Finance Working Paper No. 322/2011

Einar Bakke and Tore E. Leite

University of Gothenburg and Norwegian School of Economics $(\mathrm{NHH}$

Date Posted: August 14, 2010

Last Revised: January 12, 2012

Working Paper Series

194 downloads 
Why Micro-Prudential Regulation Fails? The Impact on Systemic Risk by Imposing a Capital Requirement 24th Australasian Finance and Banking Conference 2011 Paper

Chen Zhou

Bank of the Netherlands

Date Posted: March 16, 2010

Last Revised: October 12, 2011

Working Paper Series

207 downloads

CEO Incentives and Institutional Trader Monitoring are Substitutes: Theory and Evidence AFA 2012 Chicago Meetings Paper, 24th Australasian Finance and Banking Conference 2011 Paper Brandon Chen and Peter L. Swan

Victoria University of Wellington and University of New South Wales (UNSW)

Date Posted: January 25, 2010

Last Revised: January 03, 2012

Working Paper Series

192 downloads

Adverse Information and Mutual Fund Runs

24th Australasian Finance and Banking Conference 2011 Paper

Meijun Qian and Bassak Tanyeri

National University of Singapore and Bilkent University

Date Posted: March 20, 2009

Last Revised: August 28, 2011

Working Paper Series

101 downloads

Banking Market Structure, Liquidity Needs, and Industrial Volatility

24th Australasian Finance and Banking Conference 2011 Paper

Jiaren Pang, Yanping Shi and Haibin Wu

Tsinghua University - School of Economics \& Management, University of International Business and Economics - School of International Trade and Economics and University of Alberta - School of Business

Date Posted: February 26, 2009

Last Revised: November 24, 2011

Working Paper Series

105 downloads

Stocking Up: Executive Optimism and Share Retention

AFA 2010 Atlanta Meetings Paper, 24th Australasian Finance and Banking Conference 2011 Paper

Rik Sen and Robert Tumarkin

Hong Kong University of Science and Technology and University of New South Wales (UNSW) - School of Banking and Finance Date Posted: February 18, 2009

Last Revised: March 19, 2012

Working Paper Series

109 downloads 


\section{Australian School of Business}

\section{Australasian Finance \& Banking Conference FAQs}

\section{Frequently Asked Questions (FAQ)}

1. How many papers can I submit to the conference?

Each author may only submit one paper to the conference.

If you wish to submit more than one paper, you will need to ensure that the co-author of your paper will be available to present your paper, should it be accepted into the conference. There is a limit of one paper presentation per author.

\section{I am a PhD Student. Can I get financial as sistance?}

The registration fee for $\mathrm{PhD}$ Students is reduced. The conference is unable to provide any further financial assistance.

Students from Asia, Europe and North America that have been accepted to present at the PhD Forum receive up to AUD \$2000 airfare and accommodation assistance.

\section{Are the papers peer reviewed?}

All submitted papers undergo a peer review process before being accepted for presentation at the Australasian Finance \& Banking Conference (AFBC). Full papers undergo a blind review process by a selection committee independent of the author.

\section{How do I submit a paper? Can I submit via email?}

We only accept paper submissions via SSRN. Please note, paper submissions via email will not be processed. The submission link for the $25^{\text {th }}$ AFBC is as follows: http://hq.ssrn.com/conference=25th-Australasian-2012

\section{What is the submission deadline?}

You will need to submit your paper by Monday 20 August 2012.

\section{Are there any format requirements for the paper?}

The paper should follow the format that you usually see in major international journals. If you are unsure of the format, please consult with your supervisor or colleagues. There is no specific page limit. Please note however, the paper submission must be an actual paper and not just the abstract.

\section{How do I revise my paper?}

- Login to SSRN

- Go to 'My Papers'

- $\quad$ Find your paper and click 'revise'.

- Please ensure that you make all necessary changes, including uploading the new PDFs of your paper

- Once you have made all changes, you must click "Submit Revision". If you do not do this, your paper will not be successfully revised and the paper reviewer will not see the changes you have made

\section{Can I revise my paper after submission and during the reviewing process?}

Yes, after you submit your paper you can revise your paper on SSRN. However, if you revise your paper during the reviewing period, it cannot be guaranteed that the reviewer will see this update. Hence, please ensure that you make all necessary revisions before the submission deadline. 